\title{
Single-Cell $\mathrm{C}_{4}$ Photosynthesis Versus the Dual-Cell (Kranz) Paradigm
}

\author{
Gerald E. Edwards, ${ }^{1}$ Vincent R. Franceschi, ${ }^{1}$ \\ and Elena V. Voznesenskaya ${ }^{2}$ \\ ${ }^{1}$ School of Biological Sciences, Washington State University, Pullman, \\ Washington 99164-4236; email: edwardsg@wsu.edu,vfrances@mail.wsu.edu \\ ${ }^{2}$ Laboratory of Anatomy and Morphology, V. L. Komarov Botanical Institute of Russian \\ Academy of Sciences, Prof. Popov Street 2, 197376, St. Petersburg, Russia; \\ email:elena@jp2058.spb.edu
}

Key Words $\mathrm{C}_{4}$ plants, Chenopodiaceae, dimorphic chloroplasts,
immunolocalization of photosynthetic enzymes, leaf anatomy, photosynthesis

- Abstract The efficiency of photosynthetic carbon assimilation in higher plants faces significant limitations due to the oxygenase activity of the enzyme Rubisco, particularly under warmer temperatures or water stress. A drop in atmospheric $\mathrm{CO}_{2}$ and rise in $\mathrm{O}_{2}$ as early as 300 mya provided selective pressure for the evolution of mechanisms to concentrate $\mathrm{CO}_{2}$ around Rubisco in order to minimize oxygenase activity and the resultant loss of carbon through photorespiration. It is well established that a carbon-concentrating mechanism occurs in some terrestrial plants through the process of $\mathrm{C}_{4}$ photosynthesis. These plants are characterized as having Kranz-type leaf anatomy, with two structurally and biochemically specialized photosynthetic cell types, mesophyll and bundle sheath, that function coordinately in carbon assimilation. $\mathrm{C}_{4}$ photosynthesis has evolved independently many times with great diversity in forms of Kranz anatomy, structure of dimorphic chloroplasts, and biochemistry of the $\mathrm{C}_{4}$ cycle. The most dramatic variants of $\mathrm{C}_{4}$ terrestrial plants were discovered recently in two species, Bienertia cycloptera and Borszczowia aralocaspica (family Chenopodiaceae); each has novel compartmentation to accomplish $\mathrm{C}_{4}$ photosynthesis within a single chlorenchyma cell. This review discusses the amazing diversity in $\mathrm{C}_{4}$ systems, how the essential features of $\mathrm{C}_{4}$ are accomplished in single-cell versus Kranz-type $\mathrm{C}_{4}$ plants, and speculates on why single-cell $\mathrm{C}_{4}$ plants evolved.

\section{CONTENTS}

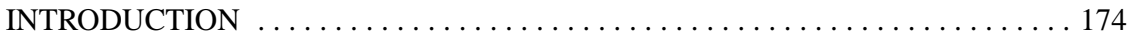

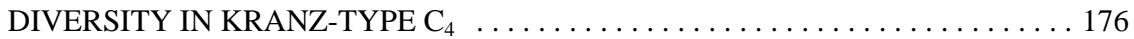

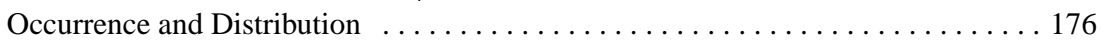

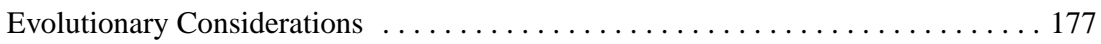

The Link Between Anatomical and Biochemical Features . . . . . . . . . . 178

The Role of Dimorphic Chloroplasts in $\mathrm{C}_{4}$ Photosynthesis $\ldots \ldots \ldots \ldots \ldots$. . . . . 179 
TERRESTRIAL SINGLE-CELL $C_{4}$ PHOTOSYNTHESIS $\ldots \ldots \ldots \ldots \ldots \ldots \ldots$

Redefining How to Determine if a Terrestrial Plant $\mathrm{Is}^{C_{4}} \ldots \ldots \ldots \ldots \ldots$

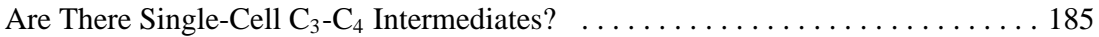

Effective Trapping of $\mathrm{CO}_{2}$ by Rubisco in Single-Cell $\mathrm{C}_{4}$ Photosynthesis $\ldots \ldots \ldots 186$

Development of Single-Cell $\mathrm{C}_{4}$ Photosynthesis $\ldots \ldots \ldots \ldots \ldots \ldots \ldots \ldots \ldots \ldots$

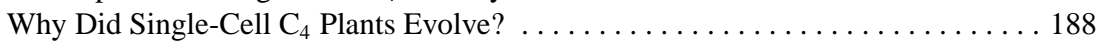

AQUATIC SINGLE-CELL C ${ }_{4}$ PHOTOSYNTHESIS $\ldots \ldots \ldots \ldots \ldots \ldots \ldots \ldots \ldots$

CONCLUSIONS: FUTURE PROSPECTS . . . . . . . . . . . . . . . . . . . . 191

\section{INTRODUCTION}

A central feature of photosynthetic carbon assimilation is the enzyme ribulose bisphosphate carboxylase-oxygenase (Rubisco; E.C. 4.1.1.39). It has a remarkably low efficiency as a catalyst due to its low turnover rate for $\mathrm{CO}_{2}$ fixation, as well as a lack of specificity for reacting only with $\mathrm{CO}_{2}$. Thus, photosynthetic organisms have had to develop means to overcome its inefficiency in carbon fixation. As a consequence, plants produce large amounts of Rubisco to compensate for its low turnover rate, resulting in its being the single most abundant soluble protein on Earth. The dual specificity of the enzyme in using $\mathrm{CO}_{2}$ and $\mathrm{O}_{2}$ as substrates presents a different problem, requiring more complex solutions. Rubisco functions both as a carboxylase and an oxygenase using the substrate ribulose1,5-bisphosphate (RuBP), with relative rates depending on the concentrations of $\mathrm{CO}_{2}$ and $\mathrm{O}_{2}$. Reaction of RuBP with $\mathrm{CO}_{2}$ leads to photosynthetic carbon reduction through the $\mathrm{C}_{3}$ cycle, providing the carbon skeleton needed for plant growth and function. In contrast, reaction of RuBP with $\mathrm{O}_{2}$ is counterproductive, leading to $\mathrm{CO}_{2}$ release through a photorespiratory process that involves the glycolate pathway. The reason why a mechanism for photosynthesis developed via this enzyme with dual catalytic activity is considered to be partly, if not totally, related to conditions existing when photosynthesis first evolved.

When photosynthesis evolved in bacteria $\sim 3$ billion years ago, carbon dioxide levels were high (circa 100-fold higher than current levels) and there was little or no oxygen $(4,61)$. Oxygenase activity, which is suggested to be an unavoidable consequence of the reaction mechanism, would therefore have been restricted by the atmospheric conditions. During the Carboniferous Period, about 300 mya, a large decline in $\mathrm{CO}_{2}$ levels and an increase in $\mathrm{O}_{2}$ levels occurred, according to geochemical mass balance models (7). This change provided conditions for significant levels of photorespiration, such that a $\mathrm{CO}_{2}$ concentrating mechanism (CCM), which enhances the ratio of $\mathrm{CO}_{2}$ to $\mathrm{O}_{2}$ around Rubisco, would be advantageous in both terrestrial and aquatic environments. It is suggested that there were multiple origins of CCMs among microalgae during the Carboniferous period (5). Although there is no supporting evidence, if land plants independently evolved CCMs during this period, these concentrating mechanisms may have been lost during the great extinction, or plants may have reverted to photosynthesis without a CCM because of a subsequent rise in $\mathrm{CO}_{2}$. Alternatively, these plants may have escaped recognition by scientists studying CCMs. During the late Tertiary Period, approximately 
65 mya, $\mathrm{CO}_{2}$ levels were again thought to be low enough for conditions to be favorable for evolutionary selection of $\mathrm{CCMs}$ and $\mathrm{C}_{4}$ photosynthesis.

Many aquatic photosynthetic organisms evolved CCMs in response to the limiting inorganic carbon and the $10^{4}$ higher diffusive resistance of $\mathrm{CO}_{2}$ in water compared with that in air. In the aquatic environment, cyanobacteria, algae, and some angiosperms evolved multiple mechanisms to actively accumulate inorganic carbon around Rubisco by use of membrane transporters and carbonic anhydrases (1a, 4, 5, 14a, 49a, 53a). In contrast, terrestrial plants, and a few aquatic macrophytes, evolved a biochemically and anatomically complex organic carbon pump, called the $\mathrm{C}_{4}$ pathway, along with the entire carbon fixation process commonly referred to as $\mathrm{C}_{4}$ photosynthesis. The earliest fossil records of $\mathrm{C}_{4}$ plants date circa 12 mya, although fossil records are sparse because most $\mathrm{C}_{4}$ plants grow in ecosystems where they are oxidized if buried (13). During the past 420,000 years, prior to industrialization, the average atmospheric $\mathrm{CO}_{2}$ concentration was only $\sim 220 \mathrm{ppm}$ (20), a level that can clearly be limiting, with high photorespiratory carbon loss in the oxygen-rich environment (55). The general requirement for $\mathrm{C}_{4}$ photosynthesis to function is the spatial separation of initial fixation of atmospheric $\mathrm{CO}_{2}$ via phosphoenolpyruvate carboxylase (PEPC) and formation of $\mathrm{C}_{4}$ acids malate and aspartate in one compartment close to the entry point of atmospheric $\mathrm{CO}_{2}$, and the utilization of these $\mathrm{C}_{4}$ acids by decarboxylases to concentrate $\mathrm{CO}_{2}$ around Rubisco in another compartment which is distal to the entry point of $\mathrm{CO}_{2}$ into photosynthetic tissue (Figure 1). From the discovery of $\mathrm{C}_{4}$ photosynthesis in the 1960 s until recently, the spatial compartmentation in terrestrial $\mathrm{C}_{4}$ plants was consistently linked to the occurrence of Kranz-type anatomy. The term Kranz anatomy is commonly used to describe the dual-cell system associated with $\mathrm{C}_{4}$ photosynthesis, consisting of mesophyll cells containing PEPC and initial reactions of $\mathrm{C}_{4}$ biochemistry, and bundle sheath cells containing enzymes for generating $\mathrm{CO}_{2}$ from $\mathrm{C}_{4}$ acids and the $\mathrm{C}_{3}$ carbon reduction pathway, including Rubisco. However, the anatomy associated

\section{$\mathrm{CO}_{2}$ pump}

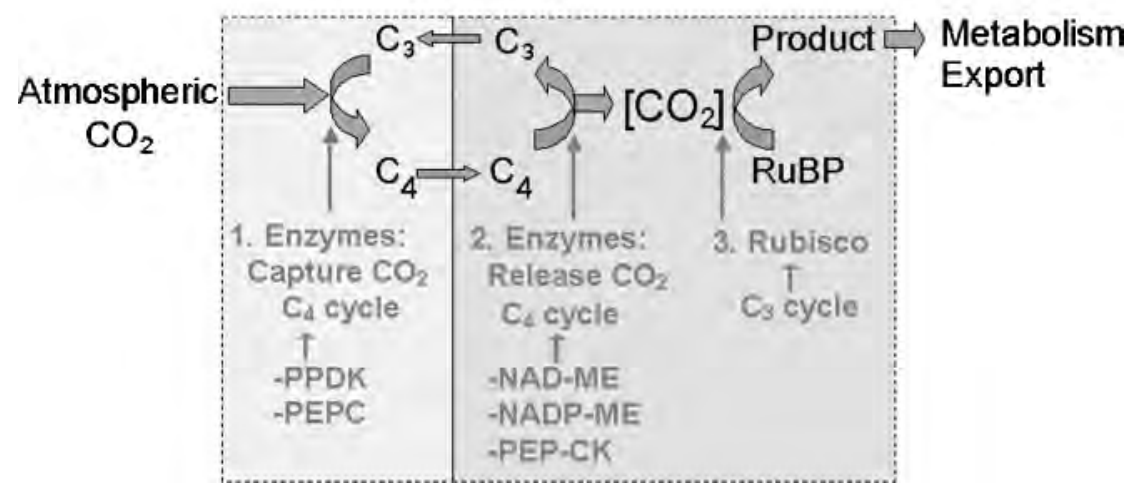

Figure 1 Compartmental depiction of the $\mathrm{CO}_{2}$ pump for $\mathrm{C}_{4}$ photosynthesis. 
with $\mathrm{C}_{4}$ plants shows considerable variation from the initial description of Kranz anatomy by Haberlandt $(31,32)$, which was made long before its association with $\mathrm{C}_{4}$ photosynthesis was discovered. A study of the structure-function relationships in the diverse $\mathrm{C}_{4}$ systems is important both for understanding of the operational parameters required for $\mathrm{C}_{4}$ photosynthesis and for exploring the evolution of the $\mathrm{C}_{4}$ syndrome.

\section{DIVERSITY IN KRANZ-TYPE $\mathrm{C}_{4}$}

\section{Occurrence and Distribution}

Among land plants, $\mathrm{C}_{4}$ species have been found to date only in angiosperms, where they have been reported in 17 of the $\sim 450$ families and in one aquatic family, Hydrocharitaceae (Table 1). Of these 18 families, the monocot family Poaceae has the largest number of $\mathrm{C}_{4}$ species (about half of the 10,000 species in the family

TABLE 1 List of families having $\mathrm{C}_{4}$ species, estimates of current number of $\mathrm{C}_{4}$ species identified, and photosynthetic types according to $\mathrm{C}_{4}$ acid decarboxylase $(59,60)$

\begin{tabular}{|c|c|c|}
\hline Family & $\begin{array}{l}\# \mathrm{C}_{4} \text { species: } \\
\text { Current estimates }\end{array}$ & $\begin{array}{l}\mathrm{C}_{4} \text { Photosynthetic types } \\
\text { identified in family }\end{array}$ \\
\hline Acanthaceae & 20 & \\
\hline Aizoaceae & 35 & \\
\hline Amaranthaceae & 250 & NAD-ME, NADP-ME \\
\hline Asteraceae & 150 & NADP-ME \\
\hline Boraginaceae & 60 & \\
\hline $\begin{array}{l}\text { Capparidaceae (now } \\
\text { in the Brassicaceae) }\end{array}$ & $10-20$ & \\
\hline Caryophyllaceae & 30 & \\
\hline Chenopodiaceae & 550 & NAD-ME, NADP-ME \\
\hline Cyperaceae & 1350 & NAD-ME, NADP-ME \\
\hline Euphorbiaceae & 250 & NADP-ME \\
\hline Hydrocharitaceae & 2 & NADP-ME \\
\hline Molluginaceae & $3-5$ & NAD-ME \\
\hline Nyctaginaceae & 25 & \\
\hline Poaceae & 4600 & NAD-ME, NADP-ME, PEP-CK \\
\hline Polygonaceae & 100 & \\
\hline Portulacaceae & 100 & NAD-ME, NADP-ME \\
\hline Scrophulariaceae & $6-10$ & \\
\hline Zygophyllaceae & 45 & NADP-ME \\
\hline
\end{tabular}


are $\mathrm{C}_{4}$ ), followed by family Cyperaceae. Among the dicots, family Chenopodiaceae has the largest number of $\mathrm{C}_{4}$ species. Compared with the more common $\mathrm{C}_{3}$ species, the total number of known $\mathrm{C}_{4}$ species is very low, currently about $3 \%$ of angiosperm species. However, $\mathrm{C}_{4}$ species have an effect on global productivity that is disproportionate to the number of species exhibiting $\mathrm{C}_{4}$ photosynthesis (discussed below). Interestingly, $\mathrm{C}_{4}$ species are primarily herbaceous or shrubby and $\mathrm{C}_{4}$ trees are rare. In contrast, although $\mathrm{C}_{3}$ herbs and shrubs are abundant, $\mathrm{C}_{3}$ trees also represent a major component of terrestrial plant biomass.

Physiological parameters that affect photosynthesis have been studied extensively in a wide range of plant species, and an understanding of these is relevant to a discussion of evolution and architecture of $\mathrm{C}_{4}$ systems. A combination of factors can contribute to $\mathrm{CO}_{2}$-limited photosynthesis in $\mathrm{C}_{3}$ plants, including low atmospheric levels of $\mathrm{CO}_{2}$, high temperature (which increases activity of RuBP oxygenase relative to carboxylase), and stomatal limitations induced by drought and high salinity (46). The importance of temperature is particularly evident from surveys of grasses at different latitudes in countries as far-ranging as Argentina, Russia, North America, and Australia $(12,33,51,66,74)$. These surveys all come to a remarkably similar conclusion: The percentage of $\mathrm{C}_{4}$ species increases linearly with decreasing latitude, with $\mathrm{C}_{4}$ species being dominant among the grasses $30^{\circ}$ north and south of the equator. The efficiency of $\mathrm{C}_{4}$ photosynthesis in warmer climates and the importance of $\mathrm{C}_{4}$ grasses in tropical and semitropical savannas account in large part for their productivity. $\mathrm{C}_{4}$ plants are estimated to contribute $\sim 20-30 \%$ to global terrestrial productivity $(25,45)$, even though they make up only about $3 \%$ of angiosperm species.

\section{Evolutionary Considerations}

Selective pressures from decreasing supply of $\mathrm{CO}_{2}$ to Rubisco driven by decreasing atmospheric $\mathrm{CO}_{2}$, high temperatures, and limitations on water availability in high light environments probably all contributed to the evolution of CCMs and $\mathrm{C}_{4}$ photosynthesis in terrestrial plants. Given that most extant $\mathrm{C}_{4}$ plants studied require a dual-cell system coupled with biochemical specialization, this complex adaptation must represent the endpoint of a stepwise mechanism of development of the system. This view is supported by studies in extant plants, where some examples of CCMs with anatomical intermediates of Kranz anatomy have been found $(17,49)$. There must have been a strong, selective pressure for the $\mathrm{C}_{4}$ type of CCM, since it is estimated that $\mathrm{C}_{4}$ photosynthesis evolved independently more than 40 times (59). This figure is likely to increase as information is provided from ongoing studies on phylogeny in families known to have $\mathrm{C}_{4}$ species. Angiosperms evolved $\sim 120$ mya, and families in which the most $\mathrm{C}_{4}$ species are found (e.g., Poaceae, Chenopodiaceae), may have evolved earlier which, over time, became more diversified in their leaf structure (facilitating evolution of Kranz anatomy) and adaptation to different habitats (56). This phase of radiation or adaptation to more varied environments where $\mathrm{C}_{4}$ still provided an advantage is thought to account 
for the variation in anatomical and biochemical features related directly to $\mathrm{C}_{4}$ photosynthesis (i.e., Kranz anatomy). Part of the anatomical variation seen in Kranz anatomy is also a reflection of leaf morphological and anatomical adaptations to other environmental pressures such as advantages of reduced leaf surface areas to volume ratios, water storage tissues, mechanical tissues, etc.

Despite evidence that $\mathrm{C}_{4}$ photosynthesis has evolved many times, why it has evolved in only a few families is not clear. Important factors for evolution of $\mathrm{C}_{4}$ are suggested to be conditions associated with climate, ecological disturbances (fire, grazing by mammals providing open high-light habitats), and differences in evolutionary diversification among plant families $(19,56)$. Furthermore, $C_{4}$ photosynthesis requires duplication of many genes followed by mutations in one of the duplicates to function in a novel role. Monson (48) suggested this duplication could result in genetic constraints where differences in population attributes (population size, generation time, frequency of recruitment of sexually produced individuals) would control the probability for evolution of $\mathrm{C}_{4}$.

\section{The Link Between Anatomical and Biochemical Features}

Plants expressing $\mathrm{C}_{4}$ photosynthesis can be categorized based on biochemistry or anatomy. $\mathrm{C}_{4}$ species have been classified biochemically according to the primary type of $\mathrm{C}_{4}$ acid decarboxylase used in $\mathrm{C}_{4}$ photosynthesis: NADP-malic enzyme (NADP-ME), NAD-malic enzyme (NAD-ME), and PEP carboxykinase (PEP-CK) (37). Although malic enzyme subtypes have often evolved independently, evidence indicates that PEP-CK type grasses are derived from ancestors having the NAD-ME subtype (41). Immunolocalization studies show clearly the selective compartmentation of key enzymes between mesophyll cells and bundle sheath cells in each of the three subgroups, which is a requirement for $\mathrm{C}_{4}$ to function. This compartmentation is illustrated in Figure 2 for Rubisco, PEPC, and the decarboxylase for species representing the three subtypes: Halothanmus glaucus, NADP-ME type (family Chenopodiaceae), Salsola laricina, NAD-ME type (family Chenopodiaceae), and Spartina anglica, PEP-CK type (Poaceae, the only family known to have PEP-CK-type $\mathrm{C}_{4}$ species). In each case, PEPC is located in mesophyll cells whereas Rubisco and the decarboxylases are localized to the bundle sheath cells. With respect to intracellular compartmentation, in each of the three biochemical types, the decarboxylases are in a different intracellular compartment in bundle sheath cells: NADP-ME in chloroplasts, NAD-ME in mitochondria, and PEP-CK in the cytosol. Rubisco is located in the chloroplasts of bundle sheath cells; pyruvate Pi dikinase (PPDK), which generates PEP for the $\mathrm{C}_{4}$ cycle, is located in the mesophyll chloroplasts; and PEPC is located in the cytosol of mesophyll cells. Thus, chloroplasts of the bundle sheath and mesophyll are different with respect to enzyme content, as well as to ultrastructural features such as relative amounts of grana and thylakoids which we will refer to as dimorphic. [See Edwards et al. (16) for a review of earlier in vitro methods for separating dimorphic chloroplasts and Kranz cell types, and recent advances using immunolocalization methods that have been instrumental in characterizing the $\mathrm{C}_{4}$ mechanism.] 
Among the families known to have $\mathrm{C}_{4}$ species, Poaceae and Chenopodiaceae have the most diversity in biochemistry and anatomy relevant to $\mathrm{C}_{4}$ photosynthesis. In the Poaceae, $\mathrm{C}_{4}$ photosynthesis is currently estimated to have evolved independently at least 10 times across three subfamilies: Panicoideae, Arundinoideae, and Chloridoideae (28). All three biochemical subtypes have been found in the grasses, and three classical types of Kranz leaf anatomy are associated with each, based on the structure of dimorphic chloroplasts and the position of chloroplasts in bundle sheath cells $(18,30)$. However, other well-known anatomical variants occur with less frequency, and sometimes are described as separate, with up to eight different Kranz-type anatomies in the family (see 15). These anatomical classes are based on the arrangement of mesophyll cells relative to the bundle sheath and other leaf cell types.

Family Chenopodiaceae has five major types of Kranz anatomy (Atriplicoid, Kochioid, Salsoloid, Kranz-Suaedoid, and Conospermoid) if arrangements of mesophyll and bundle sheath cells versus other tissues (vascular, and water storage, if present) are considered $(11,22,36)$. Also, some variants occur as anatomical subtypes with differences in the presence or absence of hypodermis and spongy parenchyma, the layout and number of vascular bundles, among other features (36). Examples of subfamilies and tribes in which these types of Kranz anatomies are found are Atriplicoid, mainly in Chenopodioideae in the tribe Atripliceae; Kochioid, also in Chenopodioideae but in the tribe Camphorosmeae; Salsoloid in Salsoloideae in the tribe Salsoleae; and Kranz-Suaedoid and Conospermoid in Suaedoideae in the tribe Suaedeae $(11,36,62)$. The chenopod $C_{4}$ species are classified into two $\mathrm{C}_{4}$ cycle biochemical subtypes, NAD-ME and NADP-ME, which usually form aspartate or malate as the predominant initial photosynthetic product, respectively $(24,26,52,53,72)$. Only NAD-ME-type $\mathrm{C}_{4}$ plants are found in members of subfamily Chenopodioideae having Atriplicoid leaf anatomy, and in members of subfamily Suaedoideae having Kranz-Suaedoid-type anatomy. Only NADP-ME species are found in Chenopodiaceae belonging to the tribe Camphorosmeae of family Chenopodioideae having Kochioid leaf anatomy, whereas in tribe Salsoleae in Salsoloideae, both biochemical subtypes are found (24, 27, $50,53) . \mathrm{C}_{4}$ members of the subfamilies Salsoloideae and Suaedoideae are predominant in biodiversity and biomass in deserts and semideserts of central Asia, where they grow under xerophytic and/or halophytic conditions with tolerance to high temperatures, drought, and salinity.

\section{The Role of Dimorphic Chloroplasts in $\mathrm{C}_{4}$ Photosynthesis}

In addition to the anatomical and biochemical differences of the Kranz cell types, the chloroplasts in mesophyll and bundle sheath cells of $\mathrm{C}_{4}$ plants are dimorphic due to differences in enzymes, location of starch (predominantly in bundle sheath chloroplasts), and in chloroplast ultrastructure. Differences in chloroplast ultrastructure are related to variations in energy requirements between mesophyll and bundle sheath cells between subgroups. High grana-containing chloroplasts have higher PSII activities and linear electron flow (producing NADPH and ATP), 
whereas low grana-containing chloroplasts are richer in PSI-mediated cyclic electron flow-producing ATP [18; also, see discussion of Anderson (3) on compartmentation of linear and cyclic electron flow between grana and stromal lamella]. This dimorphism is very apparent in NADP-ME type species, where the mesophyll chloroplasts have well-developed grana, whereas the bundle sheath chloroplasts are deficient in grana. NADP-ME type $\mathrm{C}_{4}$ species are predominantly malate formers, whereby malate is shuttled from mesophyll to bundle sheath cells. Analyses of the energetics of carbon assimilation of the two cell types in representative species show the high grana-containing mesophyll chloroplasts of NADP-ME type species to have a greater demand for reductive power (utilized in part for synthesis of malate) $(18,72)$.

NAD-ME and PEP-CK species generally have grana in both mesophyll and bundle sheath chloroplasts. However, extensive studies of NAD-ME-type species in family Chenopodiaceae show that mesophyll chloroplasts are deficient in grana compared to bundle sheath chloroplasts $(24,27,73)$. In these NAD-ME type species, aspartate is the primary product of $\mathrm{CO}_{2}$ fixation (52), and support of an aspartate cycle requires only production of ATP to drive conversion of pyruvate to PEP by the mesophyll chloroplasts $(18,72)$. This ATP may be provided via PSI cyclic electron flow in the low grana-containing chloroplasts. Thus, in general, the dimorphic nature of chloroplasts in the Kranz anatomy cells is correlated with the energy requirements of the biochemical systems that are operating.

\section{TERRESTRIAL SINGLE-CELL $\mathrm{C}_{4}$ PHOTOSYNTHESIS}

In studies on plant anatomy in the late 1800s, Haberlandt observed that some species of Cyperaceae and Poaceae have two very distinctive photosynthetic cell types that form wreaths around the vascular tissue, a formation described as Kranz anatomy $(31,32)$. When the $\mathrm{C}_{4}$ pathway of photosynthesis was discovered and the first species studied in the 1960 s, plants such as maize and sugarcane were soon recognized as having Kranz anatomy. Over the past 35 years, many $\mathrm{C}_{4}$ species have been identified (Table 1) among terrestrial plants, and where leaf anatomy has been examined, Kranz-type leaf anatomy has been synonymous with the identification of $\mathrm{C}_{4}$ photosynthesis.

Although the $\mathrm{C}_{4}$ pathway of photosynthesis was being defined in the $1960 \mathrm{~s}$, it was not until the early 1970s, when the role of Rubisco in photorespiration was discovered in $\mathrm{C}_{3}$ plants, that its function was understood. It became clear that the function of the $\mathrm{C}_{4}$ pathway is to concentrate $\mathrm{CO}_{2}$ around Rubisco in bundle sheath cells to prevent photorespiration (16). As noted above, for $\mathrm{C}_{4}$ photosynthesis to function, there needs to be spatial separation between the trapping of atmospheric $\mathrm{CO}_{2}$ into $\mathrm{C}_{4}$ acids by PEPC (not affected by $\mathrm{O}_{2}$ ) and the donation of $\mathrm{CO}_{2}$ from $\mathrm{C}_{4}$ acids to Rubisco, with sufficient diffusive resistance between the two processes to prevent $\mathrm{CO}_{2}$ leakage and futile cycling. The bundle sheath cell wall itself has been considered to be an important barrier to $\mathrm{CO}_{2}$ leakage, because of either a 
thickened cell wall or a suberin lamella in the wall (68). Kranz anatomy is an elegant evolutionary solution to separating the processes, and for more than three decades it was considered a requirement for the function of $\mathrm{C}_{4}$ photosynthesis in terrestrial plants.

Recently, this paradigm was broken when two species, Borszczowia aralocaspica and Bienertia cycloptera, both representing monotypic genera of the family Chenopodiaceae, were shown to have $\mathrm{C}_{4}$ photosynthesis within a single cell without the presence of Kranz anatomy $(58,70,71)$. Previously, these two species were reported to have $\mathrm{C}_{4} /$ Crassulacean acid metabolism (CAM)-type carbon isotope composition and unusual chlorenchyma without Kranz anatomy (2, 22, 23, 75), which suggested they are either non-Kranz $\mathrm{C}_{4}$ plants, CAM, or that they have a previously unknown type of photosynthesis mechanism. Subsequent microscopic, biochemical and physiological studies have shown these species to function as $\mathrm{C}_{4}$ plants (69-71). Although they are succulent like other related species in subfamily Suaedoideae, analyses of leaf titratable acidity at dawn and dusk, and dark $\mathrm{CO}_{2}$ exchange, show that they do not perform CAM (69-71). In fact, no CAM plants have been identified in family Chenopodiaceae; but some succulent $\mathrm{C}_{4}$ species in tribes Salsoleae and Suaedeae have been reported to have low CAM with nighttime fixation of $\mathrm{CO}_{2}$, a few percent of that fixed by photosynthesis during the day $(9,78)$.

Borszczowia grows in central Asia from northeast of the Caspian lowland east to Mongolia and western China, whereas Bienertia grows from east Anatolia eastward to Turkmenistan and Pakistani Baluchestan [see (1) for distribution of Bienertia relative to climate, soil, and other species]. From molecular and morphological studies, Borszczowia is classified in subfamily Suaedoideae with Suaeda species, forming a monophyletic group (62). From early studies on morphology, Bienertia was classified in subfamily Salsoloideae, either in tribe Suaedeae or as a separate tribe called Bienertieae. Akhani (1), who notes its evolution is still a matter of confusion, proposed that Suaeda sect. Schanginia, which has $\mathrm{C}_{3}$ species, is a possible ancestor to Bienertia. In molecular studies, Bienertia was shown to be sister to Suaedoideae in the chloroplast DNA trees; surprisingly, it was sister to subfamily Salicornioideae in a nuclear ribosomal ITS tree, despite having large morphological differences (62). The systematics of these unusual plants require further resolution.

Borszczowia and Bienertia are able to perform $\mathrm{C}_{4}$ photosynthesis within a single chlorenchyma cell by intracellular partitioning of enzymes and organelles in two compartments. However, they have two very different, and novel, means of partitioning the functions of $\mathrm{C}_{4}$ photosynthesis between two cytoplasmic compartments. Leaves of both species are terete, but their internal anatomy differs somewhat and their chlorenchyma tissue is very different. Borszczowia has a single layer of elongate, cylindrical chlorenchyma cells below the epidermal and hypodermal layers, which surround the veins and internal water storage tissue. The cells are tightly packed together with intercellular space restricted to the end of the cells closest to the epidermis. Figure $3 A$ is a confocal fluorescence mi- 
croscopy image from a Borszczowia leaf showing red autofluorescence of chloroplasts in a living cell. There is a dense layer of chloroplasts in the proximal part of the cell, which is closest to the vascular bundles and the center of the leaf, and fewer chloroplasts are located around the periphery at the distal end of the cell, which is close to the leaf surface where atmospheric $\mathrm{CO}_{2}$ enters. The anatomy of Bienertia leaves with respect to photosynthetic tissue is very different in that there are two to three layers of shorter chlorenchyma cells that surround the centrally located water-storage and vascular tissue in the leaf. The cells are loosely arranged, with considerable intercellular space around them. Confocal imaging of chloroplast autofluorescence in living cells shows a large, central cytoplasmic compartment packed with chloroplasts, and a peripheral layer of chloroplasts around the cells (Figure $3 B$ ). Scanning and transmission electron microscopy show that the cytosolic and the peripheral compartments are connected by cytoplasmic channels through the vacuole (70). This type of anatomy in Borszczowia and Bienertia, with respect to strict chloroplast partitioning, has not been reported in other plant species. Mitochondria also show strict partitioning in these two species. In Borszczowia, they are concentrated at the proximal end of the cell among the chloroplasts, and in Bienertia, they are concentrated within the central cytoplasmic compartment.

The unusual chloroplast and mitochondria partitioning and the two cytoplasmic compartments defined by this partitioning are critical components of the $\mathrm{C}_{4}$ mechanism in these species. Studies on cell structure by light, transmission electron, and scanning electron microscopy, in situ localization of key photosynthetic enzymes by light and electron microscopy, and activity and western blot assays of photosynthetic enzymes all indicate that these two species have dimorphic chloroplasts located between their two cytoplasmic compartments, which have photosynthetic functions analogous to mesophyll and bundle sheath cells in Kranz NAD-ME type $\mathrm{C}_{4}$ plants. A single Borszczowia chlorenchyma cell has the equivalent of a Kranz mesophyll compartment at the distal end and a bundle sheath compartment at the proximal end. In contrast, the Bienertia chlorenchyma cell has the equivalent of a bundle sheath cell embedded within, and surrounded by, a mesopyll cell. In both cases, there is no intervening wall between the compartments, but the connecting cytoplasmic compartments have design features that mimic the proposed function of the wall and liquid diffusion path between Kranz anatomy cell types (discussed below).

Figure $4 A$ is a model for the operation of $\mathrm{C}_{4}$ photosynthesis in a single Borszczowia chlorenchyma cell. Atmospheric $\mathrm{CO}_{2}$ enters the chlorenchyma cell at the distal end, which is surrounded by intercellular air space. Here, the carboxylation phase of the $\mathrm{C}_{4}$ pathway assimilates atmospheric $\mathrm{CO}_{2}$ into $\mathrm{C}_{4}$ acids. Two key enzymes in the process are PPDK, located in chloroplasts at the proximal part, which converts pyruvate to PEP, and PEPC, located in the cytosol, which converts PEP and bicarbonate to oxaloacetate, the precursor for forming malate and aspartate. The $\mathrm{C}_{4}$ acids diffuse to the proximal part of the cell through a thin, cytoplasmic space at the periphery of the middle of the cell, which is devoid of organelles. In the 
proximal end, the $\mathrm{C}_{4}$ acids are decarboxylated by NAD-ME in mitochondria that appear to be localized exclusively in this part of the cell. The $\mathrm{CO}_{2}$ is captured by Rubisco that is localized exclusively in chloroplasts surrounding the mitochondria in the proximal part of the cell.

Bienertia uses a similar concept of organelle partitioning in a single cell to operate the $\mathrm{C}_{4}$ process, but it has a very different compartmentation scheme. Figure $4 \mathrm{~B}$ is a model for $\mathrm{C}_{4}$ photosynthesis in Bienertia. Atmospheric $\mathrm{CO}_{2}$ enters the cell around the periphery, which is exposed to considerable intercellular air space, and here the carboxylation phase of the $\mathrm{C}_{4}$ pathway functions to convert pyruvate and $\mathrm{CO}_{2}$ into oxaloacetate through the combined action of PPDK in the chloroplast and PEPC in the cytosol. $\mathrm{C}_{4}$ acids diffuse to the central cytoplasmic compartment through cytoplasmic channels and are decarboxylated by NAD-ME in mitochondria, which are specifically and abundantly located there. Chloroplasts in the central cytoplasmic compartment surround the mitochondria and fix the $\mathrm{CO}_{2}$ by Rubisco, which is only present in the chloroplasts of this compartment, through the $\mathrm{C}_{3}$ cycle.

The specialized organelle and enzyme compartmentation established in individual Borszczowia and Bienertia chlorenchyma cells clearly mimic the organization of bundle sheath and mesophyll cells in NAD-ME type $\mathrm{C}_{4}$ species with Kranz anatomy. This compartmentation also extends to other processes in $\mathrm{C}_{4}$ photosynthesis to reduce photorespiration. In Kranz-type $\mathrm{C}_{4}$ plants, both Rubisco, which can also function as an oxygenase, and mitochondrial glycine decarboxylase (GDC) are confined to bundle sheath cells (6), where photorespiration functions as a part of the $\mathrm{CO}_{2}$ pump under limiting $\mathrm{CO}_{2}(16 \mathrm{a}, 43)$. Likewise, in these single-cell $\mathrm{C}_{4}$ plants, it is considered critical to the reduction of photorespiration that GDC, as well as the $\mathrm{C}_{4}$ acid decarboxylase NAD-ME, are located in mitochondria that occur specifically in the compartment where $\mathrm{CO}_{2}$ is captured by Rubisco in chloroplasts $(69,70)$.

The chloroplasts in the single-cell $\mathrm{C}_{4}$ system provide a particularly remarkable example of the ability to control organelle differentiation at a spatial level within an individual plant cell. In both Borszczowia and Bienertia, the chloroplasts at the site of entry of atmospheric $\mathrm{CO}_{2}$ into the $\mathrm{C}_{4}$ pathway and the site of donation of $\mathrm{CO}_{2}$ to the $\mathrm{C}_{3}$ pathway are dimorphic in three ways: enzymes (PPDK versus Rubisco and ADP glucose pyrophosphorylase, respectively), ultrastructure (grana-deficient versus high grana content, respectively), and starch (absent versus present, respectively) (69-71). These features are characteristic of dimorphic chloroplasts in mesophyll and bundle sheath cells in Kranz-type NAD-ME species in genus Atriplex, and also species in tribes Suadeae and Salsoleae $(24,27,73)$. The mechanisms regulating and maintaining this dimorphism in the single-cell system are currently under investigation and should provide important information on general mechanisms of organelle specialization and partitioning within cells as well.

Whereas partitioning of organelle-based enzyme systems can be envisioned, regardless of the complexity of the mechanisms, partitioning within a single cell 
of a major cytosolic protein such as PEPC is probably not possible. In both Borszczowia and Bienertia, PEPC is located in the cytosol, where it is probably one of the most abundant soluble proteins, but selective function of the enzyme where atmospheric $\mathrm{CO}_{2}$ enters the cell is necessary to prevent a futile $\mathrm{C}_{4}$ cycle. There are several ways by which these cells may prevent a futile cycle in the Rubiscocontaining cellular compartment. PEPC activity in this compartment may be restricted by less PEPC protein, as there is lower cytosolic space due to the high density of mitochondria and chloroplasts. PEPC activity may be limited by lack of substrate PEP, because PPDK (required to generate PEP) is essentially absent from chloroplasts in this region. There might also be selective allosteric control of PEPC activity in this compartment; e.g., regulation of activity in $\mathrm{C}_{4}$ plants by phosphorylation/dephosphorylation is well established (14). Whatever the actual mechanism is for regulating PEPC activity in the compartment where the $\mathrm{C}_{3}$ cycle functions, immunolocalization, gas exchange, $\delta^{13} \mathrm{C}$, and initial products studies all indicate that the single-cell system works effectively in the $\mathrm{C}_{4}$ mode.

\section{Redefining How to Determine if a Terrestrial Plant Is $\mathrm{C}_{4}$}

Since the 1960s, $\mathrm{C}_{4}$ photosynthesis in terrestrial plants has been linked to Kranz anatomy, although the leaf anatomy of many species classified as $\mathrm{C}_{4}$ has not been examined (16). The discovery of single-cell terrestrial $\mathrm{C}_{4}$ plants indicates that mechanisms of concentrating $\mathrm{CO}_{2}$ around Rubisco in plants may be more diverse than previously thought. Kranz anatomy is a very strong indicator of $\mathrm{C}_{4}$ photosynthesis since $\mathrm{C}_{3}$ plants lack Kranz anatomy. However, this can no longer be used as an absolute primary screen because it would not detect single-cell $\mathrm{C}_{4}$ plants. In addition, plants that have been identified as $\mathrm{C}_{4}$ based on other criteria, such as carbon isotope composition, can no longer be assumed to have Kranz anatomy.

Carbon isotope composition differs significantly between $\mathrm{C}_{3}$ and $\mathrm{C}_{4}$ or CAM plants, and this analysis provides useful information about the potential mechanism of carbon fixation in a plant $(45,76)$. Dry matter can be analyzed for ${ }^{13} \mathrm{CO}_{2}$ discrimination and if a species has a $\mathrm{C}_{3}$-type isotope composition, that characteristic would indicate unequivocally that it is functioning as a $\mathrm{C}_{3}$ plant. In $\mathrm{C}_{3}$ plants, when the rate of $\mathrm{CO}_{2}$ fixation is limited by Rubisco, there is high discrimination against assimilating ${ }^{13} \mathrm{CO}_{2}$ versus ${ }^{12} \mathrm{CO}_{2}$. In contrast, PEPC shows little discrimination against ${ }^{13} \mathrm{CO}_{2}$, and where initial fixation of atmospheric $\mathrm{CO}_{2}$ is by this enzyme, the carbon discrimination value will be low. Thus, when $\mathrm{C}_{4}$ and CAM plants fix atmospheric $\mathrm{CO}_{2}$ by PEPC, and the $\mathrm{CO}_{2}$ is effectively donated via $\mathrm{C}_{4}$ acids to Rubisco, there is no discrimination against ${ }^{13} \mathrm{CO}_{2}$. However, when photosynthesis in $\mathrm{C}_{3}$ plants is limited, primarily via diffusive resistance to $\mathrm{CO}_{2}$ (e.g., low stomatal conductance induced by drought or low humidity), these plants also show less discrimination against assimilating ${ }^{13} \mathrm{CO}_{2}(21,77)$. Hence, carbon isotope values that show reduced discrimination against ${ }^{13} \mathrm{CO}_{2}$ do not, without additional information, indicate the mode of photosynthesis. For example, if carbon isotope 
TABLE 2 Distinguishing between terrestrial single-cell $\mathrm{C}_{4}, \mathrm{CAM}$, and $\mathrm{C}_{3}$ plants

\begin{tabular}{|c|c|c|c|}
\hline Parameter & Single-cell $C_{4}$ & CAM & $\mathbf{C}_{3}$ \\
\hline Anatomy & Non-Kranz & Non-Kranz & Non-Kranz \\
\hline $\begin{array}{l}\text { Carbon isotope } \\
\text { discrimination } \\
\text { against }{ }^{13} \mathrm{CO}_{2}\end{array}$ & Low & Low to intermediate & High \\
\hline $\mathrm{C}_{4}$ pathway enzymes & High & High & Low \\
\hline Chlorenchyma & $\begin{array}{l}\text { Two cytoplasmic } \\
\text { compartments }\end{array}$ & $\begin{array}{l}\text { Large cells with } \\
\text { large vacuoles }\end{array}$ & $\begin{array}{l}\text { Palisade or spongy } \\
\text { mesophyll }\end{array}$ \\
\hline $\begin{array}{l}\text { Chloroplasts within a single } \\
\text { chlorenchyma cell }\end{array}$ & Dimorphic & Monomorphic & Monomorphic \\
\hline $\begin{array}{l}\text { Initial products of }{ }^{14} \mathrm{CO}_{2} \\
\text { fixation }\end{array}$ & $\begin{array}{l}\mathrm{C}_{4} \text { major during } \\
\text { day }\end{array}$ & $\begin{array}{l}\mathrm{C}_{4} \text { major during the } \\
\text { night }\end{array}$ & $\begin{array}{l}\mathrm{C}_{3} \text { major during } \\
\text { day }\end{array}$ \\
\hline $\begin{array}{l}\text { Diurnal fluctuation in leaf } \\
\text { acidity }\end{array}$ & No & Yes & No \\
\hline $\mathrm{CO}_{2}$ compensation point & Low & $\begin{array}{l}\text { High, late afternoon } \\
\text { uptake by the } \mathrm{C}_{3} \\
\text { pathway }\end{array}$ & High \\
\hline $\begin{array}{l}\mathrm{O}_{2} \text { inhibition of } \mathrm{CO}_{2} \\
\text { fixation measured in the } \\
\text { light }\end{array}$ & No & $\begin{array}{l}\text { Yes, late afternoon } \\
\text { uptake by the } \mathrm{C}_{3} \\
\text { pathway }\end{array}$ & Yes \\
\hline
\end{tabular}

values indicate low discrimination against ${ }^{13} \mathrm{CO}_{2}$, and microscopy indicates nonKranz anatomy, additional tests (Table 2) are needed to definitively determine if the species performs CAM, single-cell $\mathrm{C}_{4}$ photosynthesis, or diffusion-limited $\mathrm{C}_{3}$ photosynthesis.

\section{Are There Single-Cell $\mathrm{C}_{3}-\mathrm{C}_{4}$ Intermediates?}

Besides $\mathrm{C}_{4}$ photosynthesis, another means of partially overcoming the inefficiency of Rubisco, without employing a $\mathrm{C}_{4}$ cycle, is to recapture the photorespired $\mathrm{CO}_{2}$. Certain photosynthetic $\mathrm{C}_{3}-\mathrm{C}_{4}$ intermediate species have Kranz-like anatomy and reduce photorespiration by refixation of photorespired $\mathrm{CO}_{2}$ without employing $\mathrm{C}_{4}$ photosynthesis $(17,49)$. In these plants, the mesophyll functions as in $\mathrm{C}_{3}$ plants, where chloroplasts fix $\mathrm{CO}_{2}$ via the $\mathrm{C}_{3}$ cycle and produce glycolate via $\mathrm{RuBP}$ oxygenase. However, the release of $\mathrm{CO}_{2}$ in photorespiration occurs by transport of glycine to bundle sheath cells for metabolism via GDC, which is specifically expressed in bundle sheath mitochondria. The photorespired $\mathrm{CO}_{2}$ is then fixed by chloroplasts in the bundle sheath cells. A low diffusive conductance to $\mathrm{CO}_{2}$ from the bundle sheath compartment is thought to favor its refixation by RuBP carboxylase. This refixation reduces photorespiration, as is evident from the lower $\mathrm{CO}_{2}$ compensation points in intermediates, but has little effect on the carbon isotope composition 
compared to $\mathrm{C}_{3}$ plants (17). The discovery of single-cell $\mathrm{C}_{4}$ systems also indicates that mechanisms of reducing photorespiration by refixing photorespired $\mathrm{CO}_{2}$ may have evolved in plants via spatial separation of functions within chlorenchyma cells, resulting in a photosynthetic intermediate. In this case, most chloroplasts, containing Rubisco and the $\mathrm{C}_{3}$ cycle, would be partitioned at the periphery of the cell where $\mathrm{CO}_{2}$ enters from the atmosphere, whereas other chloroplasts, along with mitochondria containing GDC, would be partitioned to a distal part of the cell away from the entry of $\mathrm{CO}_{2}$. Either the positioning of chloroplasts around mitochondria and/or a long liquid-phase diffusion path could provide low conductance to $\mathrm{CO}_{2}$, favorable for refixation and lowering photorespiratory losses. Such intermediates would have lower $\mathrm{CO}_{2}$ compensation points than is typical for $\mathrm{C}_{3}$ plants, but they would not be recognized through searches for Kranz-like anatomy or screening of carbon isotope values. Evolution of single-cell photosynthetic intermediates, without $\mathrm{C}_{4}$ photosynthesis, should be less complex than single-cell $\mathrm{C}_{4}$ plants (i.e., not having dimorphic chloroplasts, or the $\mathrm{C}_{4}$ pathway), but more difficult to identify.

\section{Effective Trapping of $\mathrm{CO}_{2}$ by Rubisco in Single-Cell $\mathrm{C}_{4}$ Photosynthesis}

In $\mathrm{C}_{4}$ plants, a low conductance for diffusion of $\mathrm{CO}_{2}$ out of the bundle sheath cells relative to the conductance of Rubisco for assimilating $\mathrm{CO}_{2}$ is required for efficient operation of $\mathrm{C}_{4}$ photosynthesis. Kranz anatomy has been recognized as an efficient means of providing a physical constraint on conductance of $\mathrm{CO}_{2}$ away from Rubisco in the bundle sheath cell, although the magnitude of this diffusive resistance has been difficult to measure $(42,68)$. The bundle sheath cell wall (due to its thickness, or presence of a suberin lamella in some cases) has been considered an important component of the low diffusive conductance to $\mathrm{CO}_{2}$ and provides one explanation for the evolution of $\mathrm{C}_{4}$ photosynthesis via Kranz anatomy. Recent analyses and modeling by von Caemmerer \& Furbank (68), indicate large differences in the relative contribution of different components to this resistance in different Kranz-type $\mathrm{C}_{4}$ plants, considering bundle sheath walls, membranes, bundle sheath chloroplast position, the site of $\mathrm{C}_{4}$ acid decarboxylation, and the liquid-phase diffusion path. Considering these factors, their calculated bundle sheath resistances on a leaf area basis for different Kranz $\mathrm{C}_{4}$ subgroups ranges from circa 50 to $150 \mathrm{~m}^{2} \mathrm{~s} \mathrm{~mol}^{-1}(68)$.

Single-cell $\mathrm{C}_{4}$ plants can capture $\mathrm{CO}_{2}$ effectively from Rubisco without Kranz anatomy and the bundle sheath cell wall barrier. Photosynthesis in the single-cell systems is not inhibited by $\mathrm{O}_{2}$, even under low atmospheric levels of $\mathrm{CO}_{2}$, and their carbon isotope values are the same as in Kranz-type $\mathrm{C}_{4}$ plants $(70,71)$, whereas the values would be more negative if there were leakage of $\mathrm{CO}_{2}$ and overcycling through the $\mathrm{C}_{4}$ pathway (34). In Borszczowia, the elongated cells obviously provide a long liquid-phase diffusion path from sites of donation of $\mathrm{CO}_{2}$ from $\mathrm{C}_{4}$ acids to Rubisco in the proximal ends of the chlorenchyma cells to the intercellular 
air space at the distal ends (mean distance circa $50 \mu \mathrm{m}$ ). The thickness of the plasma membrane and cell wall is similar at the proximal and distal ends (69). The calculated diffusive resistance to $\mathrm{CO}_{2}$ in these cells through the liquid phase on a leaf area basis of $110 \mathrm{~m}^{2} \mathrm{~s}^{-1} \mathrm{~mol}^{-1}$ considering area of chlorenchyma exposed to intercellular space at the distal ends (69) is similar to values measured in the Kranz-type NAD-ME species Amaranthus edulis by utilizing plants in which the $\mathrm{C}_{4}$ cycle is inactivated (by mutation or chemically) (42). This resistance value for Borszczowia is within the range of those predicted for Kranz-type $\mathrm{C}_{4}$ plants based on analysis of physical barriers to $\mathrm{CO}_{2}$ diffusion (68); and $\mathrm{C}_{4}$ models indicate $\mathrm{CO}_{2}$ leakage and the quantum requirement per $\mathrm{CO}_{2}$ fixed increases dramatically with decreasing resistance below this value $(16 \mathrm{a}, 68)$. In both Bienertia and Borszczowia, the chloroplasts containing Rubisco are often positioned "external" to the mitochondria where $\mathrm{CO}_{2}$ is generated from malate by NAD-ME and from glycine by GDC, which may facilitate further the capture of $\mathrm{CO}_{2}$ by Rubisco. The released $\mathrm{CO}_{2}$ likely has to cross several membranes to escape from the CCM, a process that could contribute to the diffusive resistance. Just as there are alternatives in the type of $\mathrm{C}_{4}$ cycle and type of $\mathrm{C}_{4}$ anatomy, there are also alternative means of generating diffusive resistance to prevent $\mathrm{CO}_{2}$ loss from the system.

\section{Development of Single-Cell $\mathrm{C}_{4}$ Photosynthesis}

As noted above, single-cell $\mathrm{C}_{4}$ plants have two different cytoplasmic compartments. One compartment has chloroplasts containing PPDK and functions in the carboxylation phase of the $\mathrm{C}_{4}$ cycle (equivalent to the mesophyll cells in Kranz anatomy). The other compartment has chloroplasts containing Rubisco and functions in the capture of $\mathrm{CO}_{2}$ donated from $\mathrm{C}_{4}$ acids, along with mitochondria containing NAD-ME (equivalent to the bundle sheath in NAD-ME Kranz-type $\mathrm{C}_{4}$ plants). An obvious question is how this partitioning develops in single-cell $\mathrm{C}_{4}$ plants. In very young cotyledons of Borszczowia, there is one chloroplast type, which contains Rubisco, whereas PPDK is not detected and cytosolic PEPC is low (Figure 5). As the chlorenchyma develop, light-dependent spatial compartmentation for $\mathrm{C}_{4}$ photosynthesis occurs, and chloroplasts become dimorphic and are polarized to opposite ends of the cells, with PPDK in chloroplasts at the distal end and Rubisco in chloroplasts at the proximal end. Thus, during development the chloroplasts differentiate from a $\mathrm{C}_{3}$ Rubisco-containing default expression to dimorphic chloroplasts (Figure 5), the same process of differentiation as occurs in Kranz-type $\mathrm{C}_{4}$ plants $(8,15,64)$. In Kranz $\mathrm{C}_{4}$ species, where photosynthetic genes are present in both cell types, genes of the $\mathrm{C}_{4}$ pathway and the Rubisco Rbcs gene are located in the nucleus, and the Rubisco RbcL gene is located in the chloroplast $(47,64)$. If analogous, the single-cell $\mathrm{C}_{4}$ system may develop from genetically identical chloroplasts rather than from two genetically different populations of chloroplasts. Unlike the Kranz system, in the single-cell $\mathrm{C}_{4}$ system there may be selective targeting of nuclear-encoded mRNA (e.g., genes encoding PPDK and the Rubisco small subunit) to different 
cytoplasmic compartments to initially form, and then maintain, the dimorphic chloroplasts.

Part of the previous reasoning as to why $\mathrm{C}_{4}$ photosynthesis evolved with Kranz anatomy is that it allows for cell-specific expression of photosynthetic genes at multiple levels, including transcriptional control $(8,64,65)$. Thus, differential control of transcription of nuclear genes encoding photosynthetic proteins is important in developing cell-specific functions in Kranz-type anatomy. However, the occurrence of single-cell $\mathrm{C}_{4}$ plants indicates that an alternative means of spatial expression of enzymes has developed, i.e., posttranscriptional control, possibly through mRNA targeting to specific cytoplasmic compartments.

\section{Why Did Single-Cell $\mathrm{C}_{4}$ Plants Evolve?}

Single-cell $\mathrm{C}_{4}$ photosynthesis could simply be an alternative mechanism to Kranztype $\mathrm{C}_{4}$ photosynthesis although this seems to be a rare occurrence compared with the predominance of $\mathrm{Kranz}_{4}$ plants. Perhaps evolution of spatial compartmentation within a single cell is more difficult than separation of functions between two cell types. However, the extent to which this is a rarity among terrestrial plants is not known. Techniques to screen systematically for single-cell $\mathrm{C}_{4}$ plants, as discussed above, are yet to be utilized.

The single-cell $\mathrm{C}_{4}$ system, although it may be equally complex in its control of compartmentation of functions, is less complex in that it does not require the cooperative function of two cell types, nor does it require development of Kranz anatomy. Kranz anatomy in planar laminate leaves requires close spacing of veins, where most, or all, mesophyll cells are connected to a bundle sheath cell. Sage (56) suggested that the limited number of families containing species with Kranz anatomy may be linked, in part, to older families that developed more diverse types of leaf anatomy, thereby facilitating evolution of Kranz-type anatomy. Anatomical preconditions that may have facilitated evolution of Kranz anatomy are reduction in mesophyll number, increase in bundle sheath size, and increased vein density, which may have evolved in some families to maintain hydraulic integrity in hot, arid environments (56). Thus, such preconditions required for evolution of Kranz anatomy may not have developed in some families.

With respect to the two single-cell $\mathrm{C}_{4}$ systems, Borszczowia has some constraints in shape and packaging of chlorenchyma cells. Part of the chlorenchyma cell is exposed to intercellular air space where atmospheric $\mathrm{CO}_{2}$ enters, whereas the other part lacks intercellular air space, a condition that we propose helps prevent $\mathrm{CO}_{2}$ leakage from sites of $\mathrm{C}_{4}$ acid donation of $\mathrm{CO}_{2}$ to Rubisco. This may be a precondition for evolution of Borszczowia-type $\mathrm{C}_{4}$ photosynthesis. Bienertia appears to have no anatomical constraints, as it has multiple layers of chlorenchyma cells surrounded by intercellular air space. Thus, $\mathrm{C}_{3}$ plants, with a variety of leaf anatomies, could potentially function as $\mathrm{C}_{4}$ plants if they had Bienertia-type chlorenchyma cells. There are many families including rushes, onions, legumes, rose, mustard and potato, as well as gymnosperms and ferns, in which Kranztype $\mathrm{C}_{4}$ plants have not been found, yet they contain species that grow under 
conditions where $\mathrm{C}_{4}$ photosynthesis should be advantageous (56). While there may be unknown constraints in evolution of single-cell $\mathrm{C}_{4}$ photosynthesis, with these recent discoveries it is reasonable to search for alternatives to Kranz-type $\mathrm{CO}_{2}$ concentrating mechanisms among terrestrial plants.

Rather than being simply another means for achieving $\mathrm{C}_{4}$ photosynthesis, single-cell $\mathrm{C}_{4}$ might, in addition, allow more flexibility in mode of photosynthesis than Kranz-type $\mathrm{C}_{4}$ plants by, for example, shifting from $\mathrm{C}_{3}$ to $\mathrm{C}_{4}$ depending on environmental conditions (also see Hydrilla, next section). With few exceptions $(29,44 a, 67), C_{4}$ plants with $\mathrm{Kranz}$ anatomy are obligate $\mathrm{C}_{4}$. Bienertia shows some potential for a $\mathrm{C}_{3}$ to $\mathrm{C}_{4}$ transition, because under artificial growth conditions young leaves have intermediate carbon isotope values, whereas mature leaves have $\mathrm{C}_{4}$-type isotope values $(23,70)$. Though this property has not been studied systematically in natural habitats, samples collected from different geographical areas have $\mathrm{C}_{4}$ carbon isotope values $(23,70)$, indicating that they function as $\mathrm{C}_{4}$ plants. Currently, Borszczowia appears to be an obligate $\mathrm{C}_{4}$ plant, in that samples from plants growing under both natural and artificial conditions, and young versus mature leaf tissue, have $\mathrm{C}_{4}$ carbon isotope values $(22,71)$.

\section{AQUATIC SINGLE-CELL C ${ }_{4}$ PHOTOSYNTHESIS}

There are obvious differences in photosynthesis between aquatic and terrestrial plants. Whereas terrestrial plants take $\mathrm{CO}_{2}$ from the atmosphere, both $\mathrm{CO}_{2}$ and bicarbonate are available in the aquatic environment. Leaf polarity occurs in some aquatic macrophytes such as $\mathrm{Hydrilla}$, facilitating uptake of $\mathrm{CO}_{2}$ by acidification at the adaxial side of the leaf as it shifts the equilibrium from bicarbonate to $\mathrm{CO}_{2}$. Nevertheless, if the concentration of inorganic carbon is low, the high diffusive resistance to inorganic carbon in water could limit the internal concentration in the cytosol (analogous to a high stomatal resistance in terrestrial plants as stomata close), making it beneficial to have $\mathrm{C}_{4}$ photosynthesis. In this case, the $\mathrm{C}_{4}$ pump in an aquatic plant may be beneficial even with a low intracellular diffusive resistance to $\mathrm{CO}_{2}$ and substantial overcycling of the $\mathrm{C}_{4}$ pathway.

Several freshwater monocots can perform $\mathrm{C}_{4}$ photosynthesis under submerged conditions without Kranz anatomy. These include the submerged species Hydrilla verticillata and Egeria densa in family Hydrocharitaceae, Sagittaria subulata in family Alismataceae $(10,44)$, and species of Orcuttia in family Poaceace when growing submerged (38-40). Extensive studies have been made with Hydrilla, a facultative $\mathrm{C}_{4}$ species, which is induced from $\mathrm{C}_{3}$ to $\mathrm{C}_{4}$ photosynthesis when exposed to low $\mathrm{CO}_{2}$. There is evidence that it performs $\mathrm{C}_{3}$ photosynthesis in the winter under cooler conditions and higher concentrations of inorganic carbon, and $\mathrm{C}_{4}$ photosynthesis in the summer under warmer temperatures and lower levels of inorganic carbon. Hydrilla is NADP-ME-type $\mathrm{C}_{4}$, where the proposed cycle is fixation of atmospheric $\mathrm{CO}_{2}$ in the cytosol via PEPC, import of oxaloacetate or asparate into the chloroplast, followed by reduction of oxaloacetate to malate by NADP-malate dehydrogenase, and decarboxylation of malate via NADP-ME, 
generating $\mathrm{CO}_{2}$ and pyruvate. The released $\mathrm{CO}_{2}$ is fixed by Rubisco, the pyruvate is converted to PEP via PPDK, and PEP is exported from the chloroplast to the cytosol to complete the cycle. Although there is evidence that $\mathrm{CO}_{2}$ is concentrated in Hydrilla cells during $\mathrm{C}_{4}$ photosynthesis, it is not known how it could be concentrated in the chloroplast, and what prevents high $\mathrm{CO}_{2}$ leakage and futile $\mathrm{C}_{4}$ pathway cycling. There is no evidence for dimorphic chloroplasts in Hydrilla analogous to Kranz-type NADP-ME species. Modeling a single-cell $\mathrm{C}_{4}$ system such as Hydrilla with $\mathrm{C}_{4}$ acid decarboxylation in the chloroplast shows that the low resistance normally expected of the chloroplast envelope to $\mathrm{CO}_{2}$ $\left(1.25 \mathrm{~m}^{2} \mathrm{~s}^{-1} \mathrm{~mol}^{-1}\right)$ would result in a very limited CCM (68).

Another interesting, but mechanistically different, type of inducible CCM occurs in some species of Eleocharis (Cyperaceae), which perform $\mathrm{C}_{3}$ photosynthesis when submerged and are induced to perform $\mathrm{C}_{4}$ or $\mathrm{C}_{3}-\mathrm{C}_{4}$ intermediate photosynthesis when emerged (i.e., above the water surface). Eleocharis accomplishes $\mathrm{C}_{4}$ photosynthesis, not through a single-cell system, but through development of Kranzlike anatomy and expression of $\mathrm{C}_{4}$ enzymes in the emerged part of the plant (67).

$\mathrm{C}_{4}$ photosynthesis in the genus Orcuttia is particularly interesting. Orcuttia species grow in seasonal pools formed by rain in California. They germinate and produce terete leaves when submerged, and then form laminate leaves when floating on the water and during continued growth as the pools dry up. Pulse-chase experiments with ${ }^{14} \mathrm{CO}_{2^{-}}{ }^{12} \mathrm{CO}_{2}$ with $O$. viscida and $O$. californica indicate that these species perform $\mathrm{C}_{4}$ photosynthesis without Kranz anatomy when growing under submerged conditions, and $\mathrm{C}_{4}$ photosynthesis with Kranz anatomy when foliage is terrestrial (38-40). O. viscida is an NADP-ME species that has mesophyll-like cells when growing submerged, with chloroplasts in a centripetal position. The proposed mechanism of photosynthesis is like that of Hydrilla, with $\mathrm{CO}_{2}$ fixation via PEPC in the cytosol, and donation of $\mathrm{CO}_{2}$ from malate via chloroplastic NADPME to Rubisco. Interestingly, the location of chloroplasts in the centripetal position may provide liquid-phase diffusive resistance to $\mathrm{CO}_{2}$, enabling it to be concentrated and fixed by Rubisco. According to this proposal, chloroplasts that develop in mesophyll-like chlorenchyma cells in submerged leaves may be functionally more like the bundle sheath chloroplasts in Kranz-type leaves that develop under terrestrial conditions. However, a CCM has not been established for photosynthesis in submerged Orcuttia, and the intracellular mechanism of photosynthesis needs to be elucidated through studies on enzyme compartmentation. Species of Orcuttia are rare and endangered owing to loss of habitat, whereas Hydrilla is a serious invasive species.

There is also substantial evidence for function of a $\mathrm{CCM}$ through a $\mathrm{C}_{4}$ cycle in the marine macroalga Udotea flabellum, indicating $\mathrm{C}_{4}$ type photosynthesis has evolved outside of the angiosperms (10). Finally, it is important to make the distinction that microalgae have CCMs, not through $\mathrm{C}_{4}$ photosynthesis, but by other mechanisms. Although $\mathrm{C}_{4}$ photosynthesis has been suggested in the marine diatom Thalassiosira weissflogii under low zinc nutrition and $\mathrm{CO}_{2}(54)$, whether it functions as a CCM has been questioned (35). 


\section{CONCLUSIONS: FUTURE PROSPECTS}

Much is known about terrestrial $\mathrm{C}_{4}$ plants with Kranz anatomy, including their occurrence, significance, and mechanism of photosynthesis. Until recently, it was thought that all terrestrial $\mathrm{C}_{4}$ plants have Kranz anatomy. With the discovery of terrestrial single-cell $\mathrm{C}_{4}$ species, new questions have arisen. Are these species rare, or have single-cell systems for reducing photorespiration gone undetected until now? A broader search is needed among terrestrial plants for modifications in photosynthesis within a single cell that reduce photorespiration, whether by development of $\mathrm{C}_{4}$ cycle, or by refixation of photorespired $\mathrm{CO}_{2}$ at sites in the cell distal to the entry of atmospheric $\mathrm{CO}_{2}$. What are the advantages and disadvantages of the single-cell systems with respect to dual-cell $\mathrm{C}_{4}$ photosynthetic systems? Is the single-cell system more efficient under certain environmental conditions, or does it impart more flexibility, such as allowing for $\mathrm{C}_{3}$ photosynthesis under certain conditions?

Single-cell $\mathrm{C}_{4}$ photosynthesis in terrestrial chenopods is of the NAD-ME type and occurs through compartmentation of structurally and biochemically dimorphic chloroplasts, and polarization of mitochondria containing NAD-ME and GDC. The dimorphic chloroplasts in the single cell serve the same functions as the dimorphic chloroplasts in Kranz-type NAD-ME $\mathrm{C}_{4}$ species. Many facets of single-cell $\mathrm{C}_{4}$ photosynthesis in terrestrial plants are yet to be elucidated. What are the mechanisms for development of spatial separation of functions, including ultrastructural and biochemical changes in the organelles, partitioning of organelles in different compartments within an individual cell, phased expression of certain $\mathrm{C}_{4}$ photosynthesis genes, and targeting of the mRNA from these genes or the gene product to the correct compartments of the cell?

Other interesting mechanistic variations of single-cell $\mathrm{C}_{4}$ may well be found through further targeted searches. For example, in the aquatic monocots Hydrilla and Orcuttia, single-cell $\mathrm{C}_{4}$ photosynthesis is classified as NADP-ME type. In these plants, the functions of dimorphic chloroplasts found in terrestrial Kranz-type NADP-ME species, including PPDK in mesophyll chloroplasts and NADP-ME and Rubisco in bundle sheath chloroplasts, are proposed to be combined into one chloroplast type. This chloroplast would function to donate carbon from malate to Rubisco and to generate PEP, the substrate for cytosolic PEPC, through the combined actions of NADP-ME, Rubisco, and PPDK. Further biochemical and immunolocalization studies will be needed to confirm this proposed mechanism.

In any single-cell $\mathrm{C}_{4}$ system, an important consideration is the diffusive resistance for $\mathrm{CO}_{2}$ from sites of $\mathrm{C}_{4}$ acid donation to Rubisco. How is this achieved, and is it sufficient to function as efficiently as Kranz-type $\mathrm{C}_{4}$ plants? The effectiveness of concentrating $\mathrm{CO}_{2}$ around Rubisco from donors of $\mathrm{C}_{4}$ acids depends on the rate of $\mathrm{CO}_{2}$ generation by $\mathrm{C}_{4}$ acid decarboxylation (turnover of the $\mathrm{C}_{4}$ cycle), diffusive resistance to leakage away from sites of decarboxylation, and the rate of carboxylation by Rubisco. If some single-cell $\mathrm{C}_{4}$ species have a low diffusive resistance to $\mathrm{CO}_{2}$ leakage, $\mathrm{CO}_{2}$ could still be concentrated around Rubisco under special 
circumstances, i.e., provided there is a high rate of $\mathrm{C}_{4}$ acid decarboxylation and low Rubisco capacity. This might be advantageous by preventing photorespiration and increasing photosynthesis when the supply of external $\mathrm{CO}_{2}$ to the leaf is very limited, despite an increased expense of $\mathrm{C}_{4}$ pathway overcycling, which would be reflected in lower quantum yields and more negative carbon isotope values. In general, there are currently two types of single-cell $\mathrm{C}_{4}$ systems. One is monomorphic (one chloroplast type that contains Rubisco, the $\mathrm{C}_{3}$ cycle, and a $\mathrm{C}_{4}$ acid decarboxylase), represented by the aquatic single-cell $\mathrm{C}_{4}$ plants, and by current genetic engineering efforts to introduce $\mathrm{C}_{4}$ photosynthesis into $\mathrm{C}_{3}$ crops. The other is dimorphic (two chloroplast types with spatial compartmentation within the cell analogous to that in Kranz-type anatomy) as found in the single-cell $\mathrm{C}_{4}$ chenopods. Modeling studies show that the monomorphic system has limited ability to concentrate $\mathrm{CO}_{2}$ in the chloroplast and a high energetic cost when considering the low diffusive resistance that exists between the chloroplast and intercellular space as in $\mathrm{C}_{3}$ plants. However, it could be valuable when intercellular levels of $\mathrm{CO}_{2}$ are low (67a, 68), e.g., due to drought and low stomatal conductance in terrestrial plants, or high boundary-layer resistance in aquatic plants.

These systems, terrestrial and aquatic, demonstrate the remarkable plasticity inherent in the plant cell, and they provide unusual examples of the exquisite control of subcellular processes that can be exerted to accomplish very complicated biochemical functions. With interest in genetic engineering of important $\mathrm{C}_{3}$ crop plants such as rice to perform $\mathrm{C}_{4}$ photosynthesis (63), the invention by nature of single-cell $\mathrm{C}_{4}$ photosynthesis provides evidence that this may be an alternative to engineering $\mathrm{C}_{3}$ plants to perform Kranz-type $\mathrm{C}_{4}$ photosynthesis without having to engineer a dual-cell system.

\section{ACKNOWLEDGMENTS}

Our research has been supported by NSF (Division of Integrative Biology and Neuroscience and Division of Molecular and Cellular Biosciences), IBN-98,07916, IBN-01,31098, IBN-02,36959 and award number RB1-2502-ST-03 of the U.S. Civilian Research and Development Foundation for the Independent States of the Former Soviet Union, and by a Fulbright Fellowship to E.V. We thank O. Kiirats for his comments on the manuscript and the Washington State University Electron Microscopy Center for use of their facilities.

\section{The Annual Review of Plant Biology is online at http://plant.annualreviews.org}

\section{LITERATURE CITED}

1. Akhani H, Ghobadnejhad M, Hashemi SMH. 2003. Ecology, biogeography, and pollen morphology of Bienertia cycloptera Bunge ex Boiss. (Chenopodi- aceae), an enigmatic $\mathrm{C}_{4}$ plant without Kranz anatomy. Plant Biol. 5:167-78

1a. 2002. $\mathrm{CO}_{2}$ Concentrating mechanisms in aquatic photosynthetic organisms. IVth 
Int. Symp. Inorganic Carbon Utilisation by Aquatic Photosynthetic Organisms. Funct. Plant Biology 29:117-416

2. Akhani H, Trimborn P, Ziegler H. 1997. Photosynthetic pathways in Chenopodiaceae from Africa, Asia and Europe with their ecological, phytogeographical and taxonomical importance. Plant Syst. Evol. 206:187-221

3. Anderson JM. 1999. Insights into the consequences of grana stacking of thylakoid membranes in vascular plants: a personal perspective. Aust. J. Plant Physiol. 26:625-39

4. Badger M. 2003. The role of carbonic anhydrases in photosynthetic $\mathrm{CO}_{2}$ concentrating mechanisms. Photosyn. Res. 77:83-94

5. Badger MR, Price GD. 2003. $\mathrm{CO}_{2}$ concentrating mechanisms in cyanobacteria: molecular components, their diversity and evolution. J. Exp. Bot. 54:609-22

6. Bauwe H, Kolukisaoglu U. 2003. Genetic manipulation of glycine decarboxylation. J. Exp. Bot. 54:1523-35

7. Berner RA. 1998. The carbon cycle and $\mathrm{CO}_{2}$ over Phanerozoic time: the role of land plants. Philos. Trans. R. Soc. London Ser. B. 353:75-82

8. Berry J, McCormac D, Long J, Boinski JJ, Corey A. 1997. Photosynthetic gene expression in amaranth, an NAD-ME type $\mathrm{C}_{4}$ dicot. Aust. J. Plant Physiol. 24:42328

9. Bil' KY, Lyubimov VY, Demidova RN, Gedemov T. 1982. Assimilation of $\mathrm{CO}_{2}$ by plants of Chenopodiaceae family with three types of autotrophic tissues in the leaves. Soviet Plant Physiol. 28:808-15

10. Bowes G, Rao SK, Estavillo GM, Reiskind JB. 2002. $\mathrm{C}_{4}$ mechanisms in aquatic angiosperms: comparisons with terrestrial $\mathrm{C}_{4}$ systems. Funct. Plant Biol. 29:379-92

11. Carolin RC, Jacobs SWL, Vesk M. 1975. Leaf structure in Chenopodiaceae. Bot. Jahrb. Syst. Pflanzengesch. Pflanzengeogr. 95:226-55
12. Cavagnaro JB. 1988. Distribution of $\mathrm{C}_{3}$ and $\mathrm{C}_{4}$ grasses at different altitudes in a temperate arid region of Argentina. Oecologia 76:273-77

13. Cerling TE. 1999. Paleorecords of $\mathrm{C}_{4}$ plants and ecosystems. See Ref. 60a, pp. 445-69

14. Chollet R, Vidal J. 1996. Phosphoenolpyruvate carboxylase: a ubiquitous, highly regulated enzyme in plants. Annu. Rev. Plant Physiol. 47:293-98

14a. Colman B, Huertas IE, Bhatti S, Dason JS. 2002. The diversity of inorganic carbon acquisition mechanisms in eukaryotic microalgae. Funct. Plant Biology 29:26170

15. Dengler NG, Nelson T. 1999. Leaf structure and development in $\mathrm{C}_{4}$ plants. See Ref. 60a, pp. 133-72

16. Edwards GE, Franceschi VR, Ku MSB, Voznesenskaya EV, Pyankov VI, Andreo CS. 2001. Compartmentation of photosynthesis in cells and tissues of $\mathrm{C}_{4}$ plants. J. Exp. Bot. 52:577-90

16a. Edwards GE, Kiirats O, Laisk A, Okita TW. 2000. Requirements for the $\mathrm{CO}_{2}-$ concentrating mechanism in $\mathrm{C}_{4}$ plants relative to limitations on carbon assimilation in rice. See Ref. 63, pp. 99-112

17. Edwards GE, Ku MSB. 1987. The biochemistry of $\mathrm{C}_{3}-\mathrm{C}_{4}$ intermediates. In The Biochemistry of Plants. Vol. 10. Photosynthesis, ed. MD Hatch, NK Boardman, pp. 275-325. New York: Academic

18. Edwards GE, Walker DA. 1983. $C_{3}, C_{4}$ : Mechanisms, and Cellular and Environmental Regulation, of Photosynthesis. Oxford: Blackwell Sci. 542 pp.

19. Ehleringer JR, Sage RF, Flanagan LB, Pearcy RW. 1991. Climate change and the evolution of $\mathrm{C}_{4}$ photosynthesis. Trends Ecol. Evol. 6:3:95-99

20. Falkowski P, Scholes RJ, Boyle E, Canadell J, Canfield D, et al. 2000. The global carbon cycle: a test of our knowledge of Earth as a system. Science 290:291-96

21. Farquhar GD, Ehleringer JR, Hubick KT. 
1989. Carbon isotope discrimination and photosynthesis. Annu. Rev. Plant Physiol. Plant Mol. Biol. 40:503-37

22. Freitag H, Stichler W. 2000. A remarkable new leaf type with unusual photosynthetic tissue in a Central Asiatic genus of Chenopodiaceae. Plant Biol. 2:154-60

23. Freitag H, Stichler W. 2002. Bienertia cycloptera Bunge ex Boiss., Chenopodiaceae, another $\mathrm{C}_{4}$ plant without Kranz tissues. Plant Biol. 4:121-32

24. Gamaley YV, Voznesenskaya EV. 1986. Structural-biochemical types of C-4 plants. Soviet Plant Physiol. 33:616-30

25. Gillion J, Yakir D. 2001. Influence of carbonic anhydrase activity in terrestrial vegetation on the ${ }^{18} \mathrm{O}$ content of atmospheric $\mathrm{CO}_{2}$. Science 291:2584-87

26. Glagoleva TA, Chulanovskaya MV. 1992. Photosynthetic metabolism in plants of Chenopodiaceae family from arid saline regions. Fiziol Rast. 39:671-79

27. Glagoleva TA, Voznesenskaya EV, Kolchevsky KG, Kocharyan NI, Pakhomova MV, et al. 1990. Structural and functional characteristics of halophytes from the Ararat. Fiziol Rast. 37:1080-88

28. Guissani LM, Cota-Sanches JH, Zuloaga FO, Kellogg EA. 2001. A molecular phylogeny of the grass subfamily Panicoideae (Poaceae) shows multiple origins of $\mathrm{C}_{4}$ photosynthesis. Am. J. Bot. 88:1993-2012

29. Guralnick LJ, Edwards GE, Ku MSB, Hockema B, Franceschi VR. 2002. Photosynthetic and anatomical characteristics in the $\mathrm{C}_{4}$-Crassulacean acid metabolismcycling plant, Portulaca grandiflora. Funct. Plant Biol. 29:763-73

30. Gutierrez M, Gracen VE, Edwards GE. 1974. Biochemical and cytological relationships in $\mathrm{C}_{4}$ plants. Planta 119:279300

31. Haberlandt G. 1896. Physiologische Pflanzenanatomie. Leipzig: Wilhelm Engelman

32. Haberlandt G. 1914. Physiological Plant Anatomy. London: Macmillan. 777 pp.

33. Hattersley PW. 1983. The distribution of
$\mathrm{C}_{3}$ and $\mathrm{C}_{4}$ grasses in Australia in relation to climate. Oecologia 57:113-28

34. Henderson S, von Caemmerer S, Farquhar GD. 1992. Short-term measurements of carbon isotope discrimination in several $\mathrm{C}_{4}$ species. Aust. J. Plant Physiol. 19:26385

35. Johnston AM, Raven JA, Beardall J, Leegood RC. 2001. Photosynthesis in a marine diatom. Nature 412:40-41

36. Kadereit G, Borsch T, Weising K, Freitag H. 2003. Phylogeny of Amaranthaceae and Chenopodiaceae and the evolution of $\mathrm{C}_{4}$ photosynthesis. Int. J. Plant Sci. 164:959-86

37. Kanai R, Edwards G. 1999. The biochemistry of $\mathrm{C}_{4}$ photosynthesis. See Ref. 60a, pp. 49-87

38. Keeley JE. 1998. C 4 photosynthesis modifications in the evolutionary transition from land to water in aquatic grasses. $\mathrm{Oe}$ cologia 116:85-97

39. Keeley JE. 1999. Photosynthetic pathway diversity in a seasonal pool community. Funct. Ecol. 13:106-18

40. Keeley JE, Rundel PW. 2003. Evolution of $\mathrm{CAM}$ and $\mathrm{C}_{4}$ carbon-concentrating mechanisms. Int. J. Plant Sci. 164:55-77

41. Kellogg EA. 1999. Phylogenetic aspects of the evolution of $\mathrm{C}_{4}$ photosynthesis. See Ref. 60a, pp. 411-44

42. Kiirats O, Lea PJ, Franceschi VR, Edwards GE. 2002. Bundle sheath diffusive resistance to $\mathrm{CO}_{2}$ and effectiveness of $\mathrm{C}_{4}$ photosynthesis and refixation of photorespired $\mathrm{CO}_{2}$ in a $\mathrm{C}_{4}$ cycle mutant and wild-type Amaranthus edulis. Plant Physiol. 130:964-76

43. Laisk A, Edwards G. 2000. A mathematical model of $\mathrm{C}_{4}$ photosynthesis: the mechanism of concentrating $\mathrm{CO}_{2}$ in NADPmalic enzyme type species. Photosyn. Res. 66:199-224

44. Lara M, Casati P, Andreo CS. 2002. $\mathrm{CO}_{2}$-concentrating mechanisms in Egeria densa, a submersed aquatic plant. Physiol. Plant. 115:487-95

44a. Lara MV, Disante KB, Podesta FE, 
Andreo CS, Drincovich MF. 2003. Induction of a Crassulacean acid like metabolism in the $\mathrm{C}_{4}$ succulent plant, Portulaca oleracea L.: physiological and morphological changes are accompanied by specific modifications in phosphoenolpyruvate carboxylase. Photosyn. Res. 77:241-54

45. Lloyd J, Farquhar GD. 1994. $\delta^{13} \mathrm{C}$ discrimination during $\mathrm{CO}_{2}$ assimilation by the terrestrial biosphere. Oecologia 99:201-15

46. Long SP. 1999. Environmental responses. See Ref. 60a, pp. 215-49

47. Matsuoka M, Furbank RT, Fukayama H, Miyao M. 2001. Molecular engineering of $\mathrm{C}_{4}$ photosynthesis. Annu. Rev. Plant Physiol. Plant Mol. Biol. 52:297-314

48. Monson RK. 2003. Gene duplication, neofunctionalization, and the evolution of $\mathrm{C}_{4}$ photosynthesis. Int. J. Plant Sci. 164:43-54

49. Monson RK, Rawsthorne S. 2000. $\mathrm{CO}_{2}$ assimilation in $\mathrm{C}_{3}-\mathrm{C}_{4}$ intermediate plants. In Photosynthesis: Physiology and metabolism, ed. RC Leegood, TD Sharkey, S von Caemmerer, pp. 533-50. Dordrecht: Kluwer

49a. Ogawa T, Kaplan A. 2003. Inorganic carbon acquisition systems in cyanobacteria. Photosyn. Res. 77:105-15

50. Pyankov VI, Artyusheva EG, Edwards GE, Black CC, Soltis PS. 2001. Phylogenetic analysis of tribe Salsoleae of Chenopodiaceae based on ribosomal ITS sequences: implications for the evolution of photosynthetic types. Am. J. Bot. 88:1189-98

51. Pyankov VI, Gunin PD, Tsoog S, Black CC. $2000 . \mathrm{C}_{4}$ plants in the vegetation of Mongolia: their natural occurrence and geographical distribution in relation to climate. Oecologia 123:15-31

52. P'yankov VI, Vakhrusheva DV. 1989. Pathways of primary $\mathrm{CO}_{2}$ fixation in C-4 plants of the family Chenopodiaceae from the arid zone of Central Asia. Soviet Plant Physiol. 36:178-87
53. Pyankov VI, Voznesenskaya EV, Kuz'min AN, Ku MSB, Ganko E, et al. 2000. Occurrence of $\mathrm{C}_{3}$ and $\mathrm{C}_{4}$ photosynthesis in cotyledons and leaves of Salsola species (Chenopodiaceae). Photosyn. Res. 63:6984

53a. Raven JA. 2003. Inorganic carbon concentrating mechanisms in relation to the biology of algae. Photosyn. Res. 77:15571

54. Reinfelder JR, Kraepiel AM, Morel FM. 2000. Unicellular $C_{4}$ photosynthesis in a marine diatom. Nature 407:99699

55. Sage RF. 2001. Effects of low atmospheric $\mathrm{CO}_{2}$ on plants: more than a thing of the past. Trends Plant Sci. 6:18-24

56. Sage RF. 2001. Environmental and evolutionary preconditions for the origin and diversification of the $\mathrm{C}_{4}$ photosynthetic syndrome. Plant Biol. 3:202-13

57. Deleted in proof

58. Sage RF. 2002. $C_{4}$ photosynthesis in terrestrial plants does not require Kranz anatomy. Trends Plant Sci. 7:283-85

59. Sage RF. 2004. Atmospheric $\mathrm{CO}_{2}$, environmental stress and the evolution of $\mathrm{C}_{4}$ photosynthesis. In A History of Atmospheric $\mathrm{CO}_{2}$ and its Effects on Plants, Animals and Ecosystems., ed. JR Ehleringer, TE Cerling, D Dearing. Berlin: SpringerVerlag. In press

60. Sage RF, Li M, Monson RK. 1999. The taxonomic distribution of $\mathrm{C}_{4}$ photosynthesis. See Ref. 60a, pp. 551-84

60a. Sage RF, Monson RK, eds. 1999. C 4 Plant Biology. New York: Academic

61. Schlesinger WH. 1997. Biogeochemistry. New York: Academic. 588 pp.

62. Schütze P, Freitag H, Weising K. 2003. An intergrated molecular and morphological study of the subfamily Suaedoideae Ulbr. (Chenopodiaceae). Plant Syst. Evol. 239:257-86

63. Sheehy JE, Mitchell PL, Hardy B. 2000. Redesigning Rice Photosynthesis to Increase Yield. Makati City, Philippines: IRRI/ Elsevier Sci. 293 pp. 
64. Sheen J. 1999. C 4 gene expression. Annu. Rev. Plant Physiol. Plant Mol. Biol. 50: 187-217

65. Shu G, Pontieri V, Dengler NG, Mets LJ. 1999. Light induction of cell type differentiation and cell-type-specific gene expression in cotyledons of a $\mathrm{C}_{4}$ plant, Flaveria trinervia. Plant Physiol. 121: 731-41

66. Terri JA, Stowe LG. 1976. Climatic patterns and the distribution of grasses in North America. Oecologia 23:1-12

67. Ueno O. 2001. Environmental regulation of C-3 and C-4 differentiation in the amphibious sedge Eleocharis vivipara. Plant Physiol. 127:1524-32

67a. von Caemmerer S. 2003. $\mathrm{C}_{4}$ photosynthesis in a single $\mathrm{C}_{3}$ cell is theoretically inefficient but may ameliorate internal $\mathrm{CO}_{2}$ diffusion limitations of $\mathrm{C}_{3}$ leaves. Plant Cell Environ. 26:1191-97

68. von Caemmerer S, Furbank RT. 2003. The $\mathrm{C}_{4}$ pathway: an efficient $\mathrm{CO}_{2}$ pump. Photosyn. Res. 77:191-207

69. Voznesenskaya EV, Edwards GE, Kiirats O, Artyusheva EG, Franceschi VR. 2003. Development of biochemical specialization and organelle partitioning in the single celled $\mathrm{C}_{4}$ system in leaves of Borszczowia aralocaspica (Chenopodiaceae). Am. J. Bot. 90:166980

69a. Voznesenskaya EV, Francheschi VR, Edwards GE. 2004. Light dependent development of single cell $\mathrm{C}_{4}$ photosynthesis in cotyledons of Borszczowia aralocaspica (Chenopodiaceae) during transformation from a storage to a photosynthetic organ. Annals Bot. In press

70. Voznesenskaya EV, Franceschi VR, Kiirats O, Artyusheva EG, Freitag H, Edwards GE. 2002. Proof of $\mathrm{C}_{4}$ photosynthesis without Kranz anatomy in Biener- tia cycloptera (Chenopodiaceae). Plant J. 31:649-62

71. Voznesenskaya EV, Franceschi VR, Kiirats O, Freitag H, Edwards GE. 2001. Kranz anatomy is not essential for terrestrial $\mathrm{C}_{4}$ plant photosynthesis. Nature 414:543-46

72. Voznesenskaya EV, Franceschi VR, Pyankov VI, Edwards GE. 1999. Anatomy, chloroplast structure and compartmentation of enzymes relative to photosynthetic mechanisms in leaves and cotyledons of species in the tribe Salsoleae (Chenopodiaceae). J. Exp. Bot. 50:1779-95

73. Voznesenskaya EV, Gamaley YV. 1986. The ultrastructural characteristics of leaf types with Kranz-anatomy. Bot. Zhurn. 71:1291-307 (In Russian)

74. Wan CSM, Sage RF. 2001. Climate and the distribution of $\mathrm{C}-4$ grasses along the Atlantic and Pacific coasts of North America. Can. J. Bot. 79:474-86

75. Winter K. 1981. $\mathrm{C}_{4}$ plants of high biomass in arid regions of Asia. Occurrence of $\mathrm{C}_{4}$ photosynthesis in Chenopodiaceae and Polygonaceae from the middle east and USSR. Oecologia 48:100-6

76. Winter K, Holtum JAM. 2002. How closely do the $\delta^{13}$ values of Crassulacean acid metabolism plants reflect the proportion of $\mathrm{CO}_{2}$ fixed during day and night? Plant Physiol. 129:1843-51

77. Winter K, Holtum JAM, Edwards GE, O'Leary MH. 1982. Effect of low relative humidity on $\delta^{13} \mathrm{C}$ value in two $\mathrm{C}_{3}$ grasses and in Panicum milioides, $\mathrm{a}_{3}-\mathrm{C}_{4}$ intermediate species. J. Exp. Bot. 33:8891

78. Zalenskii OV, Glagoleva T. 1981. Pathway of carbon metabolism in halophytic desert species from Chenopodiaceae. Photosynthetica 15:244-55 

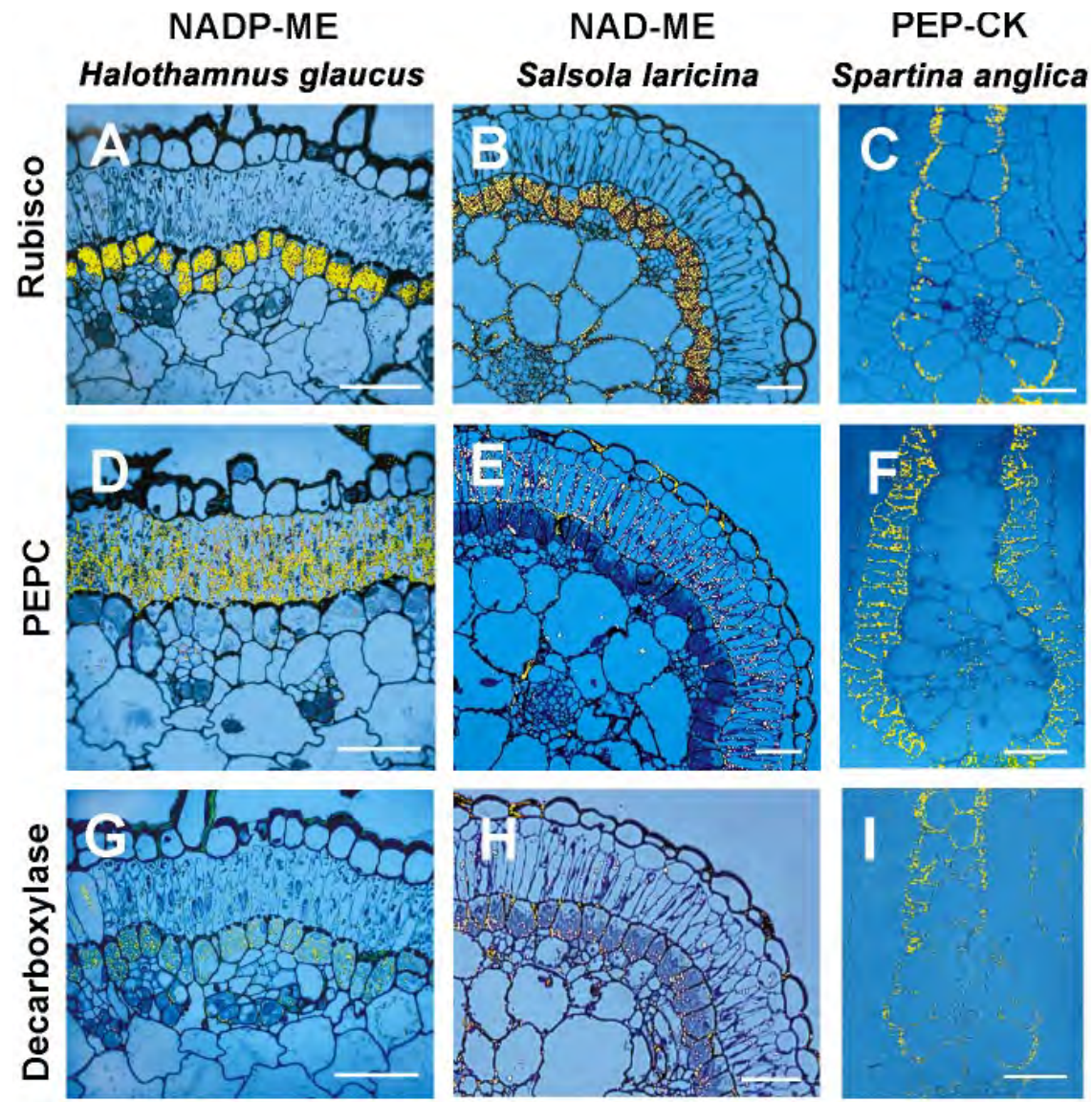

Figure 2 Illustrations of localization of three key enzymes of photosynthesis, Rubisco, PEPC, and $\mathrm{C}_{4}$ acid decarboxylating enzymes, in representative Kranz-type $\mathrm{C}_{4}$ plants: Halothanmus glaucus, NADP-ME type; Salsola laricina, NAD-ME type; and Spartina anglica, PEP-CK type. Bars $=50 \mu \mathrm{m}$. 

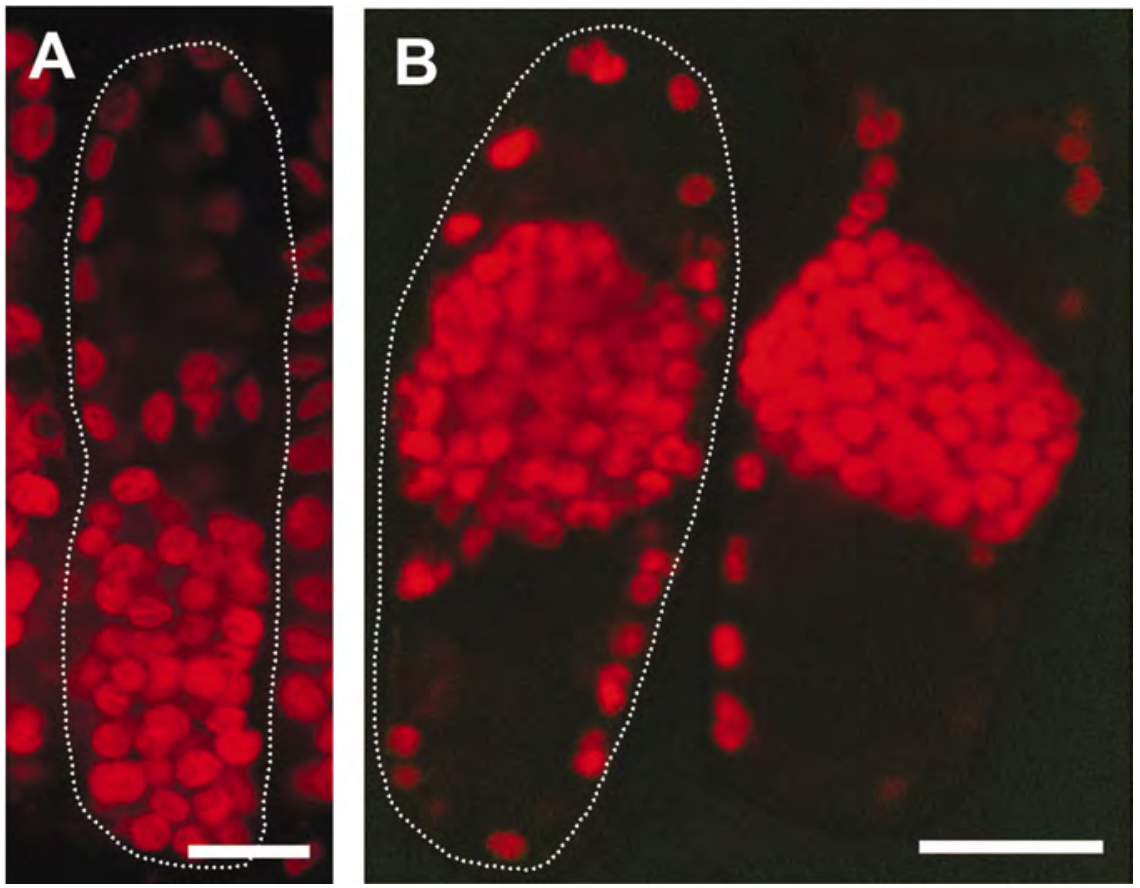

Figure 3 Confocal fluorescence of a chlorenchyma cell of Borszczowia aralocaspica $(A)$ and Bienertia cycloptera $(B)$ illustrating the chloroplasts in the two cytoplasmic compartments. The broken white lines show the outline of a single cell. Scale bars $=20 \mu \mathrm{m}$. 


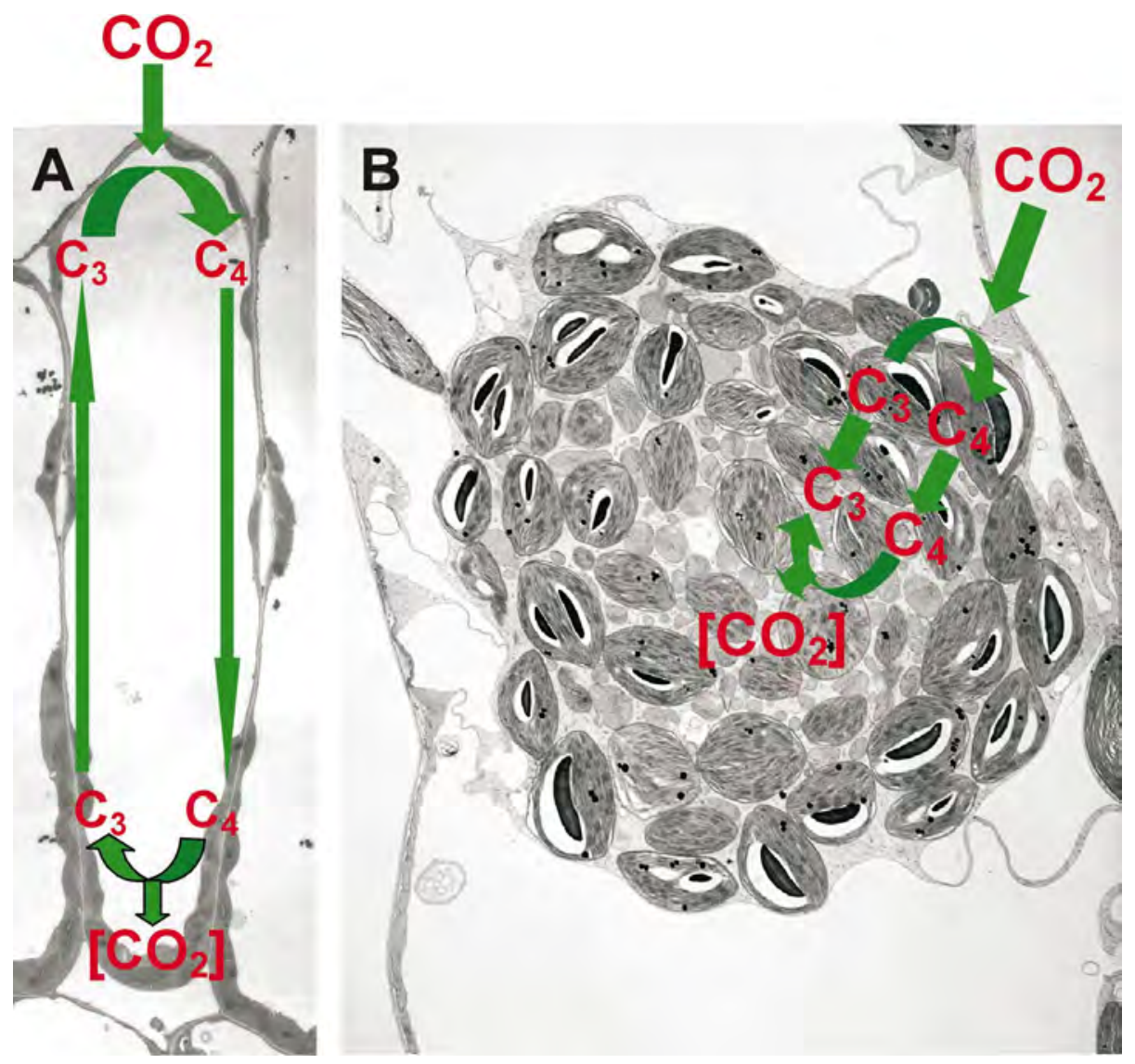

Figure 4 Electron microscopy of Borszczowia aralocaspica $(A)$ and Bienertia cycloptera (B) with overlayed schemes of the $\mathrm{C}_{4}$ cycle. 
Rubisco
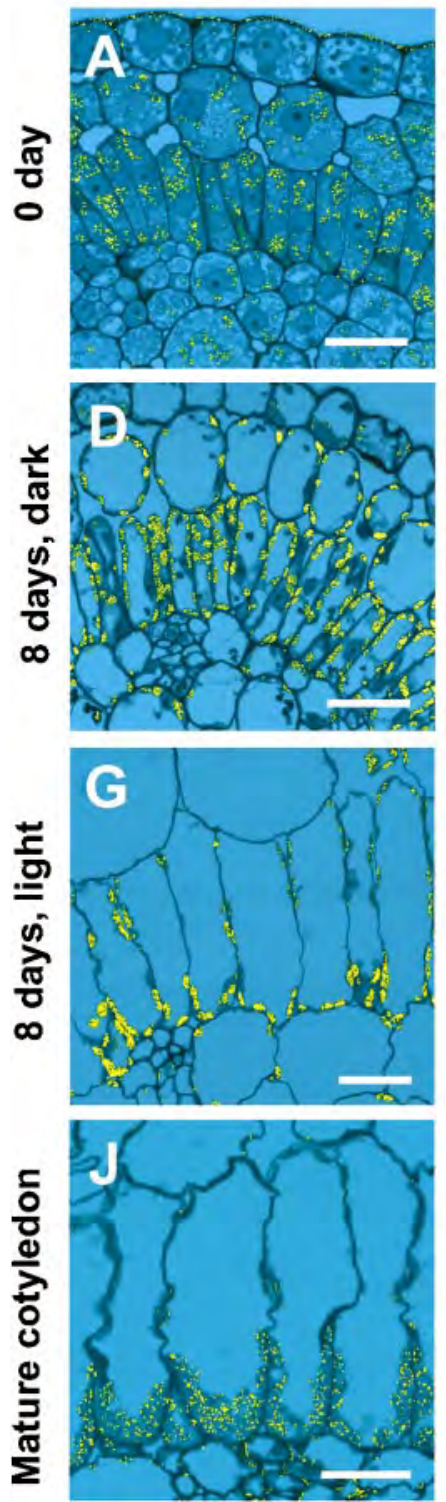

PPDK
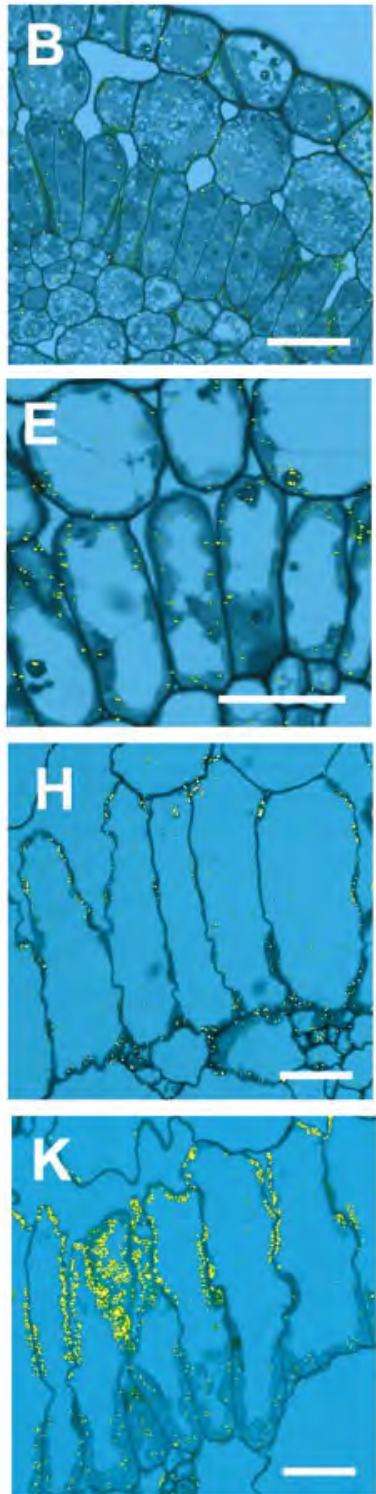

PEPC
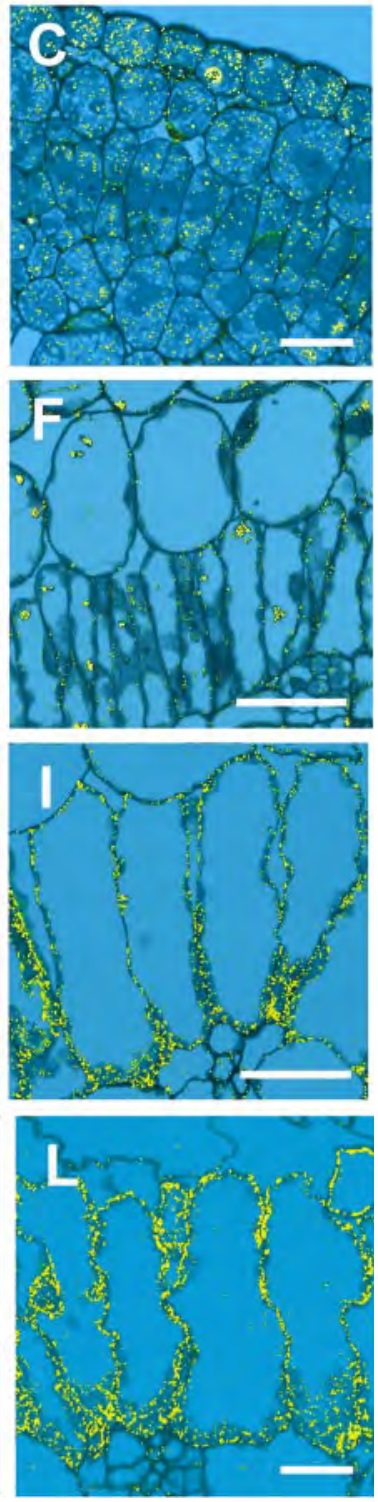

Figure 5 Reflected/transmitted confocal imaging of in situ immunolocalization of photosynthetic enzymes (Rubisco, PPDK, and PEPC) during developmental changes in chlorenchyma cells of Borszczowia aralocaspica cotyledons. Label appears as yellow dots. $(A-C)$ Cotyledon, 0 d; $(A)$ Rubisco; $(B)$ PPDK; $(C)$ PEPC; $(D-F)$ Cotyledon, 8 d, dark; $(D)$ Rubisco; $(E)$ PPDK; $(F)$ PEPC; $(G-I)$ Cotyledon, 8 d, light; $(G)$ Rubisco; $(H)$ PPDK; $(I)$ PEPC; $(J-L)$ Mature cotyledon; $(J)$ Rubisco; $(K)$ PPDK; $(L)$ PEPC. Scale bars $=20 \mu \mathrm{m}$. Figure 5 is reproduced with modifications, with permission from Annals of Botany (69a). 
党

Volume 55, 2004

\section{CONTENTS}

AN UnForeseen Voyage to the World of Phytochromes, Masaki Furuya

Alternative NAD(P)H DEHYdROGENASES OF Plant

MitOCHONDRIA, Allan G. Rasmusson, Kathleen L. Soole, and Thomas E. Elthon

DNA Methylation AND EPIGENETICS, Judith Bender

PhosphoENOLPYRUVATE CARBOXYLASE: A NEW ERA OF StRUCTURAl Biology, Katsura Izui, Hiroyoshi Matsumura, Tsuyoshi Furumoto, and Yasushi Kai

Metabolic Channeling in Plants, Brenda S.J. Winkel

RHAMNOGALACTURONAN II: STRUCTURE AND FUNCTION OF A Borate Cross-LinKed CEll Wall PeCTIC PolysaCCHARIDE, Malcolm A. O'Neill, Tadashi Ishii, Peter Albersheim, and Alan G. Darvill

NATURALLY OCCURRING GENETIC VARIATION IN ARABIDOPSIS

THALIANA, Maarten Koornneef, Carlos Alonso-Blanco, and Dick Vreugdenhil

Single-Cell $\mathrm{C}_{4}$ Photosynthesis Versus the Dual-Cell (KRANZ) PARADIGM, Gerald E. Edwards, Vincent R. Franceschi, and Elena $V$. Voznesenskaya

MoleCUlar MeChanism OF GibBERELLIN SignALING IN PLANTS, Tai-ping Sun and Frank Gubler

Phytoestrogens, Richard A. Dixon

DeCoding $\mathrm{Ca}^{2+}$ Signals Through Plant Protein Kinases, Jeffrey F. Harper, Ghislain Breton, and Alice Harmon

Plastid TRANSFORMATION In Higher Plants, Pal Maliga

SyMbioses OF GRASSES WITH SEEDBORNE FUNGAL ENDOPHYTES, Christopher L. Schardl, Adrian Leuchtmann, Martin J. Spiering

TRANSPORT MECHANISMS FOR ORGANIC FORMS OF CARBON AND NITROGEN BETWEEN SOURCE AND SINK, Sylvie Lalonde, 
Reactive OXYGen SPECiES: Metabolism, Oxidative Stress, AND Signal TRANSDUCTION, Klaus Apel and Heribert Hirt

The Generation of $\mathrm{Ca}^{2+}$ Signals in Plants,

Alistair M. Hetherington and Colin Brownlee

BIOSYNTHESIS AND ACCUMULATION OF STEROLS, Pierre Benveniste

How Do Crop Plants Tolerate ACID SoIls? MECHANISMS OF ALUMINUM TOLERANCE AND PHOSPHOROUS EFFICIENCY,

Leon V. Kochian, Owen A. Hoekenga, and Miguel A. Piñeros

VIGS VECTORS FOR GENE SLIENCING: MANY TARGETS, MANY TOOLS, Dominique Robertson

GENETIC REGULATION OF TIME TO FLOWER IN ARABIDOPSIS THALIANA, Yoshibumi Komeda

VisuALIZING CHROMOSOME STRUCTURE/ORGANIZATION, Eric Lam, Naohiro Kato, and Koichi Watanabe

The UbiQuitin 26S Proteasome Proteolytic Pathway, Jan Smalle and Richard D. Vierstra

Rising ATMOSPHERIC CARBon Dioxide: Plants FACE THE Future, Stephen P. Long, Elizabeth A. Ainsworth, Alistair Rogers, and Donald R. Ort

INDEXES

Subject Index

Cumulative Index of Contributing Authors, Volumes 45-55

Cumulative Index of Chapter Titles, Volumes 45-55

\section{ERRATA}

An online log of corrections to Annual Review of Plant Biology chapters may be found at http://plant.annualreviews.org/ 